\title{
Runoff and soil loss responses of cultivated land managed with graded soil bunds of different ages in the Upper Blue Nile basin, Ethiopia
}

\author{
Mengie Belayneh ${ }^{1,2^{*}}$ (D) Teshome Yirgu ${ }^{1}$ and Dereje Tsegaye ${ }^{3}$
}

\begin{abstract}
Background: In view of a wide range of on-site and off-site impacts of soil erosion, different soil and water conservation measures have been implemented mainly over the last two decades in the Gumara watershed and Ethiopia at large. But their effects have not been sufficiently documented, and maintenance of structures received very little attention. This study investigated the effectiveness of graded soil bunds of zero and 11 years of age in reducing runoff and soil loss. Six hydrologically isolated experimental runoff plots (three treatments $x$ two replicates) were prepared to observe rainfall, runoff, and sediment concentrations in the 2019 summer rainfall season (covering approximately $70 \%$ of the annual rainfall).
\end{abstract}

Results: Newly constructed soil bunds reduced runoff by 34.94 and $25.56 \%$ compared to the old and non-treated counterparts, respectively. Similarly, 59.6 and $48.3 \%$ soil loss reductions were observed. The amount of soil loss in non-treated plots was twice that from the new plots and even 1.6 times higher than that from the old-graded soil bund treatments. The rate of soil loss in the new- and old-graded soil bund-treated and non-treated plots was 23.5, 45.6, and $58.1 \mathrm{t} \mathrm{ha}^{-1} \mathrm{year}^{-1}$, respectively. However, the effectiveness of the old soil bunds was much lower (only 12.6 and $-21.7 \%$ in runoff and soil loss, respectively) than its new equivalent. Graded soil bunds, in its new form, reduced runoff, runoff coefficient, and soil loss significantly $(P<0.05)$. Regardless of the treatments, from the start of the rainy season to the end, runoff and runoff coefficient showed an increase, but sediment concentration decreased. Newly constructed soil bund is the most effective in reducing runoff and soil loss.

Conclusion: Graded soil bunds reduced runoff and soil loss significantly, but the rate even in the treated plots was very high when compared to both the soil loss tolerance $\left(1-6 \mathrm{t} \mathrm{ha}^{-1}\right.$ year $\left.{ }^{-1}\right)$ and formation rate $\left(10-14 \mathrm{t} \mathrm{ha}^{-1} \mathrm{year}^{-1}\right)$ estimated for the area. Hence, these structures need to be supported by other measures such as grass strips, agroforestry, and percolation ditches, for better results. Besides, regular maintenance by either removing sediments from bund furrows or increasing the bund height is recommended for sustained reduction of runoff and soil loss.

Keywords: Erosion plots, Runoff, Runoff coefficient, Sediment concentration, Soil loss

\footnotetext{
* Correspondence: mengie1980@yahoo.com

'Department of Geography and Environmental Studies, Arba Minch

University, P.O. Box 21, Arba Minch, Ethiopia

${ }^{2}$ Department of Geography and Environmental Studies, Mettu University, P.O.

Box 318, Mettu, Ethiopia

Full list of author information is available at the end of the article
}

\section{Springer Open}

(c) The Author(s). 2020 Open Access This article is licensed under a Creative Commons Attribution 4.0 International License, which permits use, sharing, adaptation, distribution and reproduction in any medium or format, as long as you give appropriate credit to the original author(s) and the source, provide a link to the Creative Commons licence, and indicate if changes were made. The images or other third party material in this article are included in the article's Creative Commons licence, unless indicated otherwise in a credit line to the material. If material is not included in the article's Creative Commons licence and your intended use is not permitted by statutory regulation or exceeds the permitted use, you will need to obtain permission directly from the copyright holder. To view a copy of this licence, visit http://creativecommons.org/licenses/by/4.0/. 


\section{Introduction}

In Ethiopia, rainfall-runoff led soil erosion is indeed a fundamental problem (Adgo et al. 2013; Tamene and Vlek 2008) and the worst in the world (Hurni et al. 2015b). It is considered to be the main driver of land degradation in the rain-feed agricultural areas of the country (Hurni et al. 2015b), significantly affecting both on-site and off-site ecosystems (Yaekob et al. 2020). The loss of top fertile soil by water erosion creates severe limitations to sustainable agricultural land use, which lead to reduced soil productivity and food insecurity (Hurni et al. 2015a; Taddese 2001; Tamene and Vlek 2008).

Soil erosion not only is jeopardizing agricultural sustainability (Hurni et al. 2015a; Tamene and Vlek 2008; Yaekob et al. 2020; Yibeltal et al. 2019) but also causes streams, lakes, dams, and reservoirs siltation (Haregeweyn et al. 2017; Tamene and Vlek 2008; Yaekob et al. 2020), and downstream ecosystem impacts (Haregeweyn et al. 2016). This can have severe impacts on irrigation agriculture and related investments in different parts of the country. In general, soil erosion has been a great challenge for agriculture both in its on-site and off-site effects. It is therefore a potential threat to the national food supply (Mekuriaw et al. 2018) and the economy of the country (Tamene and Vlek 2008).

The problem, particularly in the highlands, is widespread, and threatening as a result of long-term intensive cultivation, erosion-prone topographic, and climatic conditions (Lemma et al. 2019; Nyssen et al. 2004). Ethiopia, from its highland portions, losses 1.5 billion tonnes of soil annually, which could reduce crop yield by $1-1.5$ million tyear $^{-1}$ (Taddese 2001). Besides, Hurni et al.

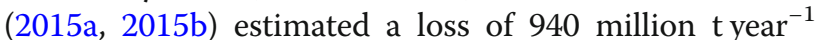
net soil from its rain-fed agricultural areas. Several model-based studies conducted in the Upper Blue Nile basin (hereafter UBNB) over the last decade show that the estimated soil erosion rate was reaching and may exceed $200 \mathrm{tha}^{-1}$ year $^{-1}$ on bare and cultivated steep slope landscapes (e.g., Belayneh et al. 2019a; Bewket and Teferi 2009; Haregeweyn et al. 2017; Mekuriaw et al. 2018). Field measurement-based studies also reported an average erosion rate of $31-37 \mathrm{tha}^{-1}$ year $^{-1}$ (Subhatu et al. 2017). The rates are much greater than both the estimated soil loss tolerance $1-6 \mathrm{t} \mathrm{ha}^{-1}$ year $^{-1}$ (Hurni 1983b) and soil formation rate of $10-14 \mathrm{t} \mathrm{ha}^{-1}$ year $^{-1}$ for Gojjam area in the UBNB (Hurni 1983a).

According to different previously studied research results, the agricultural land in the highlands is the most erosion-threatened portion in Ethiopia (Belayneh et al. 2019a; Hurni et al. 2015a; Hurni et al. 2015b; Nyssen et al. 2004). The dissected/undulating topography, high rainfall coupled with the more intensified agricultural system makes it more vulnerable to rainfall-runoff erosion. Besides, the cultivation of marginal lands, degradation of the forest for crop cultivation, and overgrazing are also considered the major factors (Adimassu et al. 2014; Hurni et al. 2015a; Nyssen et al. 2004). As a result, observable erosion features (rills, inter-rills, and gullies) are common particularly following the period of monsoon rainfall.

Considering the significant negative effects posed by soil erosion, a range of soil and water conservation (hereafter SWC) measures have been practiced in different magnitude in the Ethiopian highlands since the 1980s (e.g., Adgo et al. 2013; Adimassu et al. 2014; Dagnew et al. 2017; Dagnew et al. 2015; Haregeweyn et al. 2015), although the conservation programs were targeting frequently drought-affected areas of the northern and northeastern parts of the country (Ebabu et al. 2019; Haregeweyn et al. 2015; Mekuriaw et al. 2018). SWC practices by community mass mobilization as a nationwide 30 days public campaign work was strongly implemented since 2009 (Haregeweyn et al. 2012). At present, large-scale tree planting has been undertaken and millions of hectares of land have been treated with different conservation measures such as terraces, trenches, and percolation ponds through government-led community mass mobilization (Yaekob et al. 2020). The initiatives were targeting to reduce soil erosion (both runoff and soil loss), improving soil fertility, rehabilitation of the degraded land, and increase agricultural productivity (Mekuria et al. 2007). But, conversely, soil erosion has been increasing from 130 to 182 million metric tonnes from 1995 to 2005 (Environment for Development 2010).

The effectiveness of SWC measures was evaluated by a number of studies (e.g., Dagnew et al. 2015; Mekuria et al. 2007; Sultan et al. 2017; Taye et al. 2015; Temesgen et al. 2012). Most of them are focused on the northern and eastern arid and semi-arid parts of the country. Despite greater investment in financial and labor resources for sustainable land management, studies of runoff and soil loss reduction have been limited in the UBNB (Ebabu et al. 2019). On the other hand, the majority of these studies evaluated soil loss and runoff on newly constructed SWC structures (e.g., Adimassu et al. 2014; Dagnew et al. 2017; Sultan et al. 2017; Temesgen et al. 2012). Most of the efficiency measurements are conducted on structures with only a few years old that have sufficient furrow depressions and may not be representative of the real situations (Nyssen et al. 2007). But the ability of excavated structures to trap sediment and runoff decreases with time. Its effect more likely diminishes due to damage of structures and sediment infilling (Taye et al. 2015). Unless reconstruction and removing of sediments' that are accumulated in the bund furrows, the amount of water and sediments to be trapped 
decreases year by year. Almost all SWC implemented in the watershed were constructed by community mass mobilization, and after construction, the level of maintenance has been very low in both the community and local government. As a result, SWC structures once constructed will remain for several years without maintenance. Particularly in cultivated fields, within a few years of construction, either erosion sediments or farmers while plowing nearly totally filled furrow depressions. It has been a usual practice in the Gumara watershed, UBNB (Belayneh et al. 2019b), and most parts of Ethiopia at large.

In the Gumara watershed, in which SWC has been practiced for at least the last two decades, its effectiveness neither in its new or old forms have not been evaluated in a scientific study so far. Continuing the implementation without scientific evaluation of the impacts and its effectiveness may cause unnecessary wastage of capital, labor, time, etc. Most importantly, the objective of minimizing further soil erosion damages and land rehabilitation may not be achieved as planned.

Understanding the effectiveness of the most intensively used graded soil bund with different ages by weighing against each other and the conventional cultivation (non-treated) is vital to recommend for future sustainable watershed management plans and better management implications in the local area. The most commonly used methods to measure the effectiveness of conservation measures are soil loss ratio and runoff ratio (Maetens et al. 2012a), which are used in the present study.
The main purpose of this study was to investigate the effects of graded soil bunds of different ages on runoff, runoff coefficient, and sediment loss in the Gumara Watershed.

\section{Materials and methods}

\section{Study area}

The study area (Gumara watershed) is located in the Dega Damot district, West Gojjam Administrative Zone of Amhara region, northwestern Ethiopia (Fig. 1). The watershed is geographically located at $10^{\circ} 50^{\prime} 15^{\prime \prime}$ to $11^{\circ}$ $0^{\prime} 40^{\prime \prime} \mathrm{N}$ latitude and $37^{\circ} 30^{\prime} 40^{\prime \prime}$ to $37^{\circ} 41^{\prime} 22^{\prime \prime}$ E longitude. It covers an area of $204.4 \mathrm{~km}^{2}$. The Gumara stream is among the headwater streams of UBNB that originates from the northwestern continuation of the Choke Mountain in Gojjam. The watershed has elevations between 1864 and $3235 \mathrm{~m}$ above sea level. It is part of the northern highland dominated by the OligoMiocene volcanic trap basalt rock covered by the early tertiary volcanoes, and part of the Cenozoic volcanic and sedimentary rock formations (Abbate et al. 2015).

Typical soils' covering the watershed includes haplic luvisols, haplic nitisols, and haplic alisols (Ministry of Water Resources of Ethiopia (MoWR), 1998). Haplic alisols cover the dominant portion $(43.76 \%)$ of the watershed. The soil in the area is characterized by heavy clay content on average approximately 65\% (Belayneh et al. 2019b). The dominancy of clay soils than sand and silts can cause high runoff and sediment loss (Bashari et al.

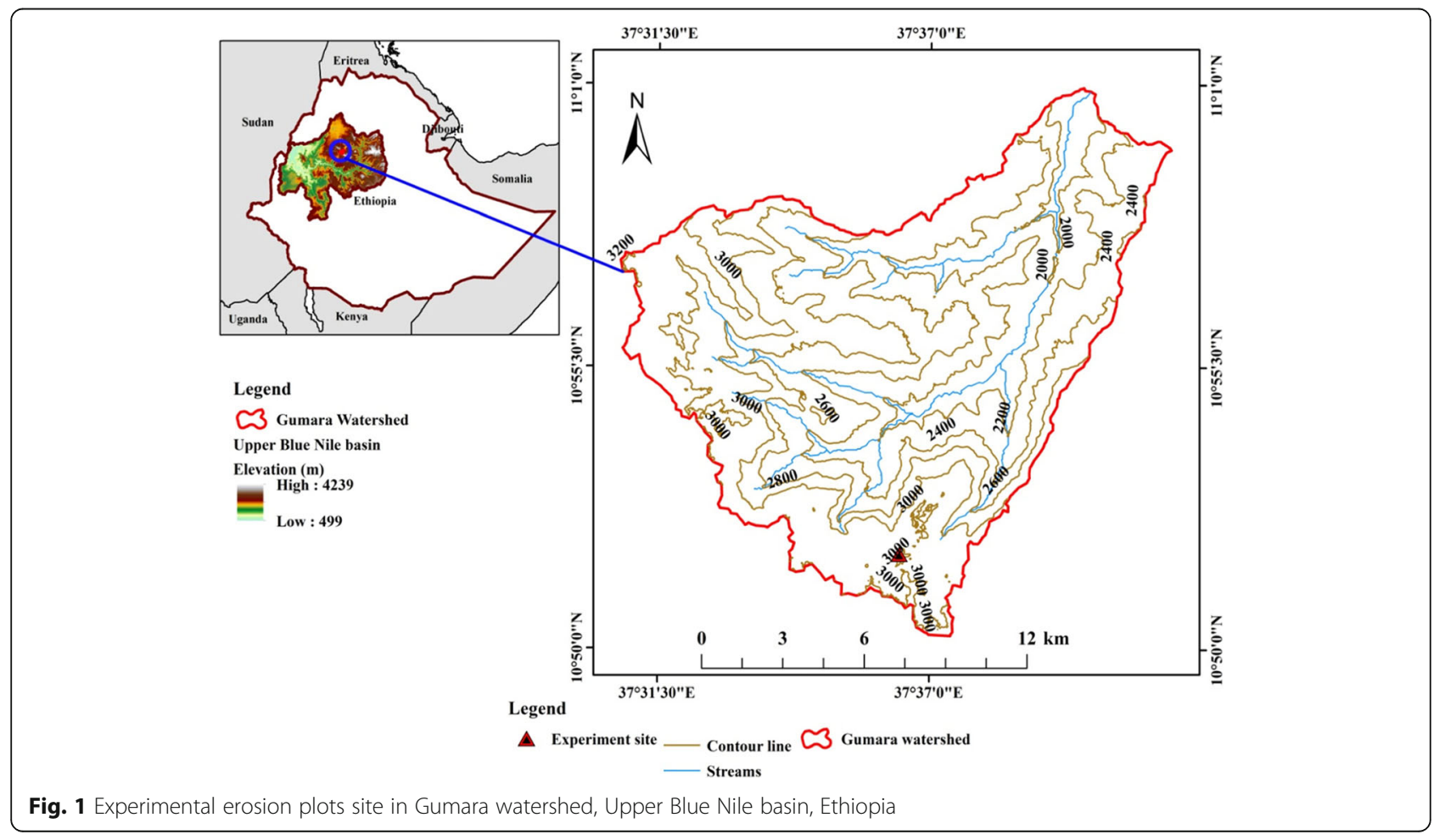


2013). Particularly at the start of the rainfall season, detachment and transport of sediments is high (Bashari et al. 2013). Heavy clay soil is distinguished as smaller infiltration capacities (Critchley et al. 1991). Its infiltration capacity strongly decreases with increasing rainfall intensity and duration (Critchley et al. 1991a). The nature of rainfall in our study area is high and torrential, which together with that of heavy clay nature of the soil makes it more vulnerable to erosion. Besides, soils have been intensively cultivated for a long period and land has been strongly degraded. Currently nearly, $90 \%$ of the local population relies on subsistence based agricultural activities with a population density of over 185 persons per square kilometer. This might be the case that the soil in the Gumara watershed is characterized by low organic carbon and total nitrogen contents (Belayneh et al. 2019b).

The mean annual rainfall is approximately 2000 mm (computed from 1997 to 2017 monthly rainfall depth data collected at Feres Bet station), received in a unimodal pattern. Rainfall varies seasonally, with approximately $80 \%$ of the rainfall occurring between May and September. The annual average temperature is $16.6^{\circ} \mathrm{C}$, ranging between a minimum value of $9{ }^{\circ} \mathrm{C}$ in January and a maximum value of $25.8^{\circ} \mathrm{C}$ in April.

Cultivated land, forestland, shrub-woodland, grazing land, settlement land, and bare land are the major land use/covers constituting the watershed. However, the watershed is considered to be an agricultural watershed, in which cultivated land and grazing land cover about $58.09 \%$ and $6.5 \%$, respectively (Belayneh et al. 2019a). Subsistence agriculture, in the form of mixed crop and livestock systems, is the main source of livelihood for about approximately $90 \%$ of the watershed community. The area is characterized by its high production potential, intensively cultivated, mixed farming, and ox-plow cereal production belt in the northwestern highlands of Ethiopia (Zeleke and Hurni 2001). The population density of the area was 184 in 2007 (Central Statistical Agency of Ethiopia (CSA) 2007).

\section{Research design}

A complete random block (CRB) design was employed. The CRB was used to design, collect, and analyze the runoff and sediment loss from experimental erosion plots. It is a type of design that a set of experimental units are grouped (blocked) in a way that reduces the variation among units within groups. It involves the principles of replication and randomization to minimize errors (Kothyari et al. 2004).

\section{Selection of experimental erosion plot site and conservation method}

A preliminary field visit was performed to select an appropriate and easily accessible study site to conduct the study. Due to different challenges related to plot scale studies, easy access to the study site is important for frequent supervision, transportation, and laboratory analysis (Hudson 1993). Experimental erosion plots were prepared in Shangi Dereke kebeles ${ }^{1}$, at the upper part of the watershed. The site is selected for three main reasons. First, it is a cultivated land and is characterized by a moderately steep slope, which represents much of the erosion of vulnerable cultivated land. Besides, unlike other land uses, SWC practices are mostly practiced on cultivated land. Second, it has been treated with graded soil bund some 11 years ago (2008) following recommended standards (mainly spacing of bunds, which is easily identifiable in its old age). It was important to compare the effectiveness of old against the newly excavated graded soil bund so as to be able to evaluate the effect of bund maintenance. Thirdly, the site is relatively accessible for easy transportation of plot equipment, supervision, and collection of rainfall and runoff data, and transportation of sample runoff for sediment concentration analysis. To study the whole watershed would have been logically and financially impossible, so we chose a moderately steep slope (18\%) cultivated plot to better observe its effectiveness on more erosion-prone cultivated lands in the watershed. Cultivated land is the most erosion-prone land use in the watershed (Belayneh et al. 2019a) and other parts of Ethiopia (Hurni et al. 2015a; Hurni et al. 2015b; Nyssen et al. 2004). Indeed, SWC measures (particularly graded soil bunds) are commonly implemented on croplands in the area.

Graded soil bund was selected as it is the most commonly used type of SWC measure in the watershed. The selected cultivated land, which had been managed with graded soil bund since 2008 was re-constructed as a new bund for new bund-treated plots ${ }^{2}\left(P_{\text {new }}\right)$, eliminated or leveled for non-treated $\operatorname{plots}^{3}\left(P_{\text {non }}\right)$, and kept as it is for old bund-treated plots ${ }^{4}\left(P_{\text {old }}\right)$. The effects of newly excavated and old-graded soil bund were compared with that of the non-treated plot (controlled). The difference between $P_{\text {new }}$ and $P_{\text {old }}$ was also studied to see the effects of age with little/no bund maintenance on runoff, runoff coefficient, and soil loss.

\footnotetext{
${ }^{1}$ Kebele is the lowest level of administration in the current Ethiopian government administration system.

${ }^{2}$ Plots treated with newly constructed graded soil bund ( 0 year).

${ }^{3}$ Plots do not have any form of soil and water conservation treatment/ old graded bund has already demolished.

${ }^{4}$ Plots treated with previously constructed (11 years old) soil bund.
} 


\section{Experimental plot preparation}

Six experimental erosion plots (three treatments with two replicates) were prepared at a slope condition of 18\% (measured by Suunto PM-5 Clinometer) on the wheat (Triticum aestivum) cultivated land. The size of the plots was $4 \times 30 \mathrm{~m}\left(120 \mathrm{~m}^{2}\right)$. Critchley et al. (1991a) indicated that it is good if the plot size is large but it is not always possible to handle the runoff generated and 3-4 $\mathrm{m}$ width and 10-12 $\mathrm{m}$ length is recommended and a minimum length of $10 \mathrm{~m}$ as is explained by Morgan (2005). Therefore, the $120 \mathrm{~m}^{2}$ plot size in this study is adequate for runoff and sediment loss measurement for comparison purposes. Plots were separated by $50-\mathrm{cm}$ long geomembrane (1-mm-thick) in which $20 \mathrm{~cm}$ was inserted to the ground to protect lateral flows from and to the surrounding area (Critchley et al. 1991a; Hudson 1993; Morgan 2005). The height of the bund at the left and right side was $5 \mathrm{~cm}$ lower to allow the flow of excess runoff towards the collection ditch, because the graded bund (that allows outflow of excess runoff from the bund furrow) in the erosion plots has already been closed and hydrologically isolated.

The total runoff generated was collected in a trench covered with a geomembrane (0.5-mm-thick) at the lower end of each plot. The size of the trench was large enough $3.8 \mathrm{~m}$ wide, $1.3 \mathrm{~m}$ deep, and $1.5 \mathrm{~m}$ long $\left(7.41 \mathrm{~m}^{3}\right.$ volume or $6.2 \%$ of the plot area) so as to handle all runoff generated from the plot (Fig. 2). The size of the trench was developed considering the maximum rainfall in the past 6 years daily rainfall and previously reported research results of the maximum runoff coefficient. Plots were randomized and replicated twice (Morgan 2005) for the quality of the result and minimize bias among treatments (Hudson 1993). Accordingly, treatments in this study were replicated twice and randomized (Fig. 2).

Newly excavated graded soil bunds were constructed following the SWC implementation guideline developed for developmental agents by the Ethiopian Ministry of Agriculture (Hurni et al. 2016) together with kebele natural resources experts.

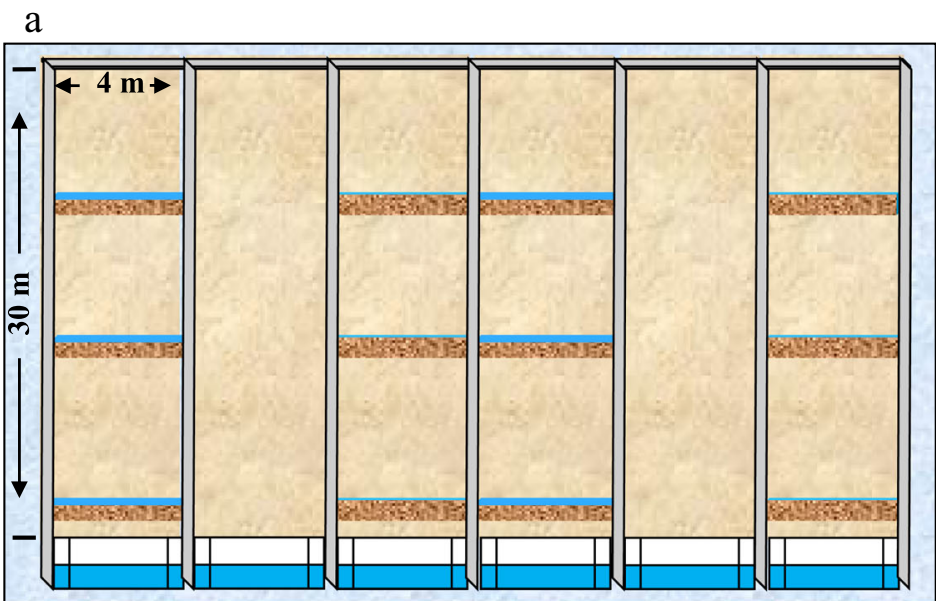

$\mathrm{b}$

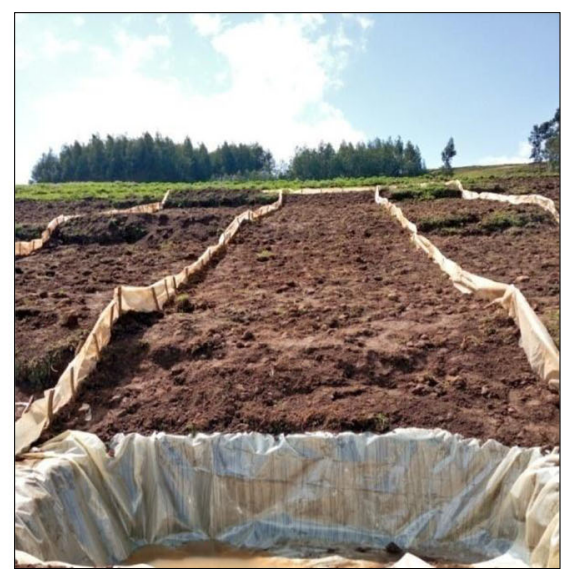

Legend

$P_{\text {new }}$ with deep furrow

20.0. $P_{\text {old }}$ with very shallow / no furrow

$P_{\text {non }}$ with no structure

Plot boundary

$\#$ Runoff collection trench

Fig. 2 A simplified representation of experimental erosion plots prepared for the study a schematic representation and $\mathbf{b}$ partial view of plot prepared at the study site 


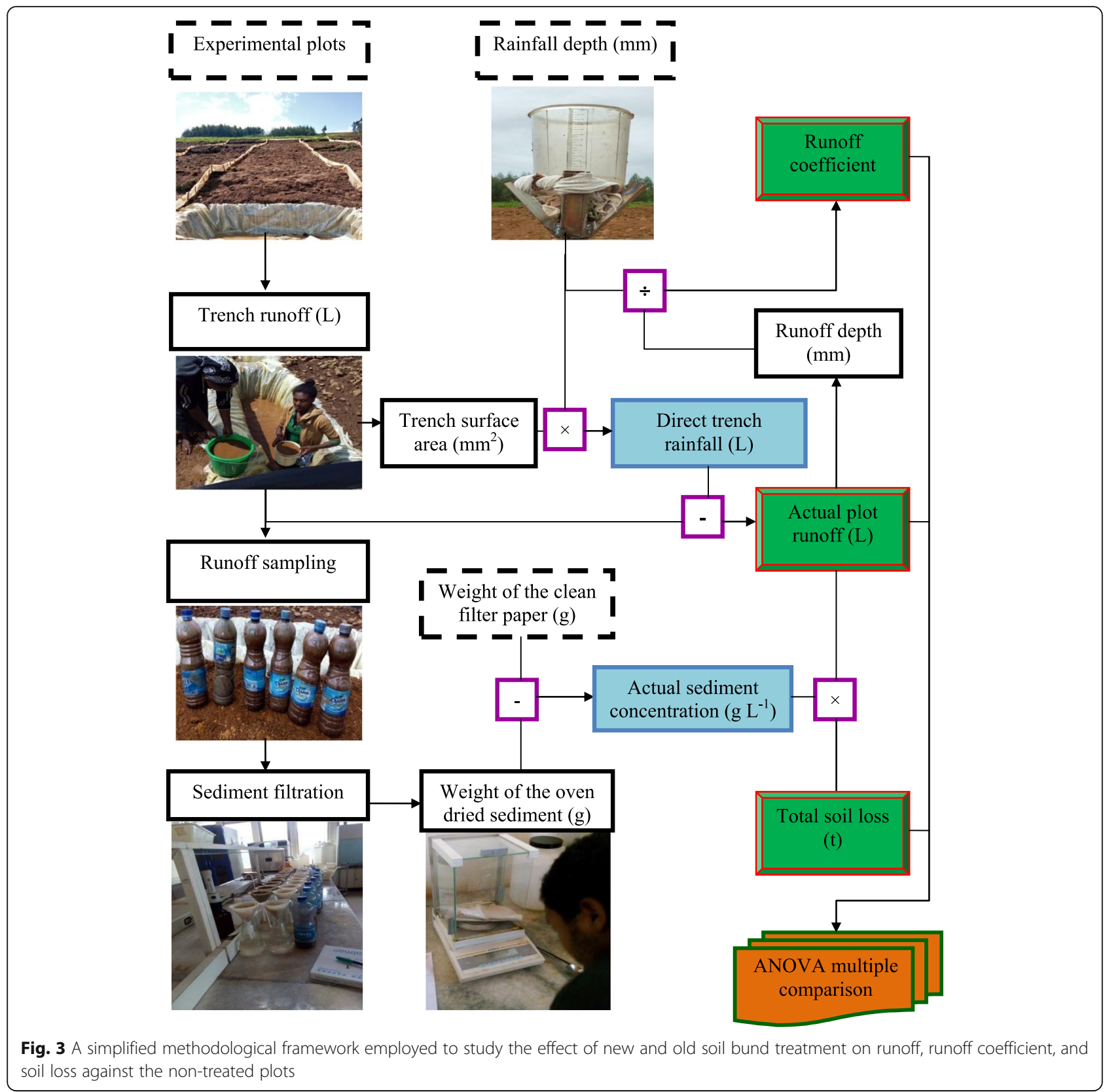

\section{Data collection}

The rainfall, runoff, and soil loss data were collected in the main monsoon rainfall season of 2019 (from June to September covering on average $\sim 70 \%$ of the annual rainfall). The total runoff accumulated in the tanker (trench) for each plot was measured using a known volume plastic tanker and recorded after $6 \mathrm{~h}$ of every erosive rainfall event $(\geq 8 \mathrm{~mm}$ of rainfall depth). Event rainfall having a depth of less than $8 \mathrm{~mm}$ yields no runoff. For soil loss determination (sediment concentration), a 1-1 runoff was sampled after thoroughly stirring the runoff collected in the trench to mix all sediment settled at the bottom (Hudson 1993). After taking sample runoff, all trenches were emptied and cleaned to make it ready for the next rainfall-runoff event.

Event rainfall depth data was measured from the site using a manual rain gauge (a plastic rain gauge collected from the National Meteorology Agency) installed in the middle of experimental erosion plots.

\section{Runoff, runoff coefficient, and sediment concentration analysis}

One-liter runoff was taken from each erosive rainfall event to estimate sediment concentration $\left(\mathrm{g} \mathrm{L}^{-1}\right.$ ) (Hudson 1993). Sample runoff was filtered with the What$\operatorname{man}^{\mathrm{TM}}$ grade-1 filter paper $(18.5-\mathrm{cm}$ diameter and 2.5- 
$\mu \mathrm{m}$ pore size) and then oven-dried for $24 \mathrm{~h}$ at $105^{\circ} \mathrm{C}$ (Sultan et al. 2017). After measuring the weight of the oven-dried filter paper using a Sartorius Type analytical balance, the mass of the clean filter paper (after filtering and oven-drying 1-liter clean water) was subtracted to find the actual soil loss (Kothyari et al. 2004). The laboratory analysis was conducted at Debre Markos soil testing laboratory and construction technology management laboratory of Debre Markos University.

Total event and monthly and annual ${ }^{5}$ runoff (in liters) generated from each plot was calculated by measuring the total runoff collected in the trench for every erosion event. The direct rainfall into the runoff collection trench was subtracted from every event rainfall total runoff. The event and monthly and annual runoff depth in millimeters was calculated as follows (Satriawan et al. 2015).

$$
R_{\mathrm{d}}=\frac{V_{\mathrm{r}}}{A_{\mathrm{p}}}
$$

where $R_{\mathrm{d}}$ is runoff depth (in millimeters), $V_{r}$ is the volume of runoff (in cubic millimeters), and $A_{\mathrm{p}}$ is plot area (in square millimeters)

Runoff coefficient $(R C)$ was determined by the ratio of runoff to the corresponding rainfall both expressed in depth (in millimeters) (Adimassu and Haile 2011; Critchley et al. 1991a). The runoff coefficient indicates how much proportion of rainfall become runoff, and the infiltration and retaining (including transpiration and evaporation) capacity of each treatment type.

$$
\mathrm{RC}=\frac{R(\mathrm{~mm})}{\mathrm{RF}(\mathrm{mm})} \times 100
$$

where $R C$ is runoff coefficient (in percent), $R$ is runoff (in millimeters), and $R F$ is rainfall (in millimeters)

Following the determination of sediment concentration (in $\mathrm{g} \mathrm{L}^{-1}$ ), the total event and monthly and annual soil losses in $\mathrm{tha}^{-1}$ were calculated as follows (Satriawan et al. 2015).

$$
\mathrm{SL}_{\mathrm{tot}}=\frac{\mathrm{SC} \times V_{r}}{A_{\mathrm{p}}} \times 10^{6}
$$

Where $S L_{\text {tot }}$ is total soil loss (in tha ${ }^{-1}$ ), $S C$ is sediment concentration (in $\mathrm{g} \mathrm{L}^{-1}$ ), $V_{r}$ is the total volume of runoff (in liters), and $A_{\mathrm{p}}$ is the area of the plot (in square meters)

\footnotetext{
${ }^{5}$ Annual rainfall, runoff, and soil loss in this study context refers to the summation value of four summer rainy months (June-September), which accounts approximately $70 \%$ of the annual rainfall.
}

\section{Statistical analysis}

One-way analysis of variance was applied to test whether there is a significant difference in runoff and runoff coefficient between $P_{\text {new }}, P_{\text {old }}$, and $P_{\text {non }}$. Although the runoff data is non-normal, if the sample size within groups is larger $(n>40)$ the sampling distribution can be normal, and using ANOVA is recommended (Elliott and Woodward 2007; Urdan 2010). The robust test of ANOVA (Welch) was used for heterogeneous soil loss data analysis because the Welch test is the best method for heterogeneous but balanced data (Liu 2015; Stevens 2007). Regression analysis was employed to show monthly and annual rainfallrunoff-soil loss relationships under different treatments. The analysis was performed using SPSS version 20 and Microsoft Excel software. Generally, the methodological procedures followed in this study to analyze runoff, runoff coefficient, and soil loss are presented in Fig. 3.

\section{Results and discussion}

The effectiveness of graded soil bunds in reducing runoff, runoff coefficient, and soil loss

A total of 112 rainfall events were recorded during the monsoon (summer) rainfall season of 2019, but 76 of the rainfall events were $\geq 8 \mathrm{~mm}$ (Table 1; Fig. 4). A rainfall depth exceeding $8 \mathrm{~mm}$ yields runoff to the runoff collection trench, and therefore, runoff, runoff coefficient, and soil loss were studied using these events. Event rainfall depth from June to September ranged from a minimum of $0.6 \mathrm{~mm}$ to as high as $65.4 \mathrm{~mm}$, with a total depth of $1732.2 \mathrm{~mm}$.

\section{Effects on runoff}

Event-based, monthly, and annual runoff and rainfall for $P_{\text {new }}, P_{\text {old }}$, and $P_{\text {non }}$ are shown in Table 1 and Fig. 4. The maximum event runoff depth of 42.07, 37.42, and 33.62 $\mathrm{mm}$ was recorded at mid-August (14 August 2019) for $P_{\text {new }}, P_{\text {old }}$, and $P_{\text {non }}$, respectively. The cumulative monthly runoff depth showed that the maximum runoff for all the treatments was recorded in August (267.63, 241.49, and $198.10 \mathrm{~mm}$ for $P_{\text {new }}, P_{\text {old }}$, and $P_{\text {non }}$, respectively), although the rainfall depth was greater in July. This might be due to the saturation of water table and lesser infiltration in $\mathrm{Au}$ gust, but the unsaturated surface and disturbance of soil aggregates by plowing creating furrows that facilitate infiltration, and on-surface storage of runoff in June and July can minimize runoff. Runoff processes in northwestern Ethiopia have been driven by saturation excess overland flow (Zegeye et al. 2016). A study by Gebreegziabher et al. (2009) showed that unlike the situation at the beginning of the rainy season, infiltration decreased and surface runoff increased significantly at its end following the saturation of the soil and the sealing of cracks formed in the dry season.

$P_{\text {new }}$ shows a greater reduction of runoff compared to that of both $P_{\text {old }}$ and $P_{\text {non }}$. However, the effect was more strong at the beginning (June, 60.13\%) than the mid 
Table 1 Monthly and annual rainfall $(R F)$, runoff $(R)$, runoff coefficient $(R C)$, and the relative effect $(R E)$ of conservation measures

\begin{tabular}{|c|c|c|c|c|c|c|c|c|c|}
\hline \multirow[t]{2}{*}{ Treatment } & \multicolumn{5}{|c|}{ Monthly } & \multicolumn{4}{|c|}{ Annually (four months) } \\
\hline & Month & $R F(\mathrm{~mm})$ & $R(\mathrm{~mm})$ & RE (\%) & $R C(\%)$ & $R F(\mathrm{~mm})$ & $R(\mathrm{~mm})$ & $R E^{\mathrm{C}}(\%)$ & $R C(\%)$ \\
\hline \multirow[t]{4}{*}{ New soil bund $\left(P_{\text {new }}\right)$} & Jun & 293.6 & 38.53 & $-60.13^{\mathrm{a}}\left(-49.5^{\mathrm{b}}\right)$ & 13.12 & 1544 & 479.85 & $-34.94^{\mathrm{a}}\left(-25.56^{\mathrm{b}}\right)$ & 31.08 \\
\hline & July & 509.3 & 175.55 & $-32.73^{a}\left(-23.1^{b}\right)$ & 34.47 & & & & \\
\hline & Aug. & 483.5 & 198.10 & $-25.98^{\mathrm{a}}\left(-18.0^{\mathrm{b}}\right)$ & 40.97 & & & & \\
\hline & Sep. & 257.6 & 67.67 & $-39.72^{\mathrm{a}}\left(-31.2^{\mathrm{b}}\right)$ & 26.27 & & & & \\
\hline \multirow[t]{4}{*}{ Old soil bund ( $\left.P_{\text {old }}\right)$} & Jun & 293.6 & 76.50 & -20.84 & 26.06 & 1544 & 644.61 & -12.60 & 41.75 \\
\hline & July & 509.3 & 228.28 & -12.53 & 44.82 & & & & \\
\hline & Aug. & 483.5 & 241.49 & -9.77 & 49.95 & & & & \\
\hline & Sep. & 257.6 & 98.34 & -12.40 & 38.18 & & & & \\
\hline \multirow[t]{4}{*}{ Non-treated $\left(P_{\text {non }}\right)$} & Jun & 293.6 & 96.64 & - & 32.91 & 1544 & 737.51 & - & 47.77 \\
\hline & July & 509.3 & 260.98 & - & 51.24 & & & & \\
\hline & Aug. & 483.5 & 267.63 & - & 55.35 & & & & \\
\hline & Sep. & 257.6 & 112.26 & - & 43.58 & & & & \\
\hline
\end{tabular}

$R F$ is total monthly and annual rainfall depth (in millimeters), $R$ is total monthly and annual runoff depth (in millimeters), $R E$ is the relative effect of treatments on runoff (in percent), $R C$ is the monthly and annual runoff coefficient (in percent), "al" and "b" are the relative effects of $P_{\text {new }}$ as compared to $P_{\text {non }}$ and $P_{\text {old }}$, respectively

${ }^{\mathrm{C}}$ The relative effect is calculated by considering the runoff from non-treated plot $100 \%$

(August, 32.37\%), and ending (September, 38\%) of the rainy season. On average, $P_{\text {new }}$ reduced the annual runoff by $34.94 \%$ as compared to the $P_{\text {non }}$. The ANOVA $F$ test result indicates that the mean differences of runoff depth among treatments are significant at $P<0.05$ (Table 2). Tukey HSD multiple comparisons further showed that $P_{\text {new }}$ significantly reduced average runoff depth compared to $P_{\text {non }}(P<0.05)$ (Table 3$)$. The consistently lower volume of runoff in the newly excavated soil bund was due to the capacity of bund furrows that can hold and infiltrate a greater proportion of runoff. It was also observed that at the end of the rainfall event the bund furrows were filled with runoff.

The effect of $P_{\text {new }}$ in runoff reduction for all events was higher, but relatively its effect decreases during high rainfall events. At the time of peak rainfall, the bund furrows quickly filled with runoff and overflows, which can lower its effect of runoff reduction. The intensity and duration of the rainfall events can also affect the runoff rate regardless of the rainfall depth. For instance, the depth of

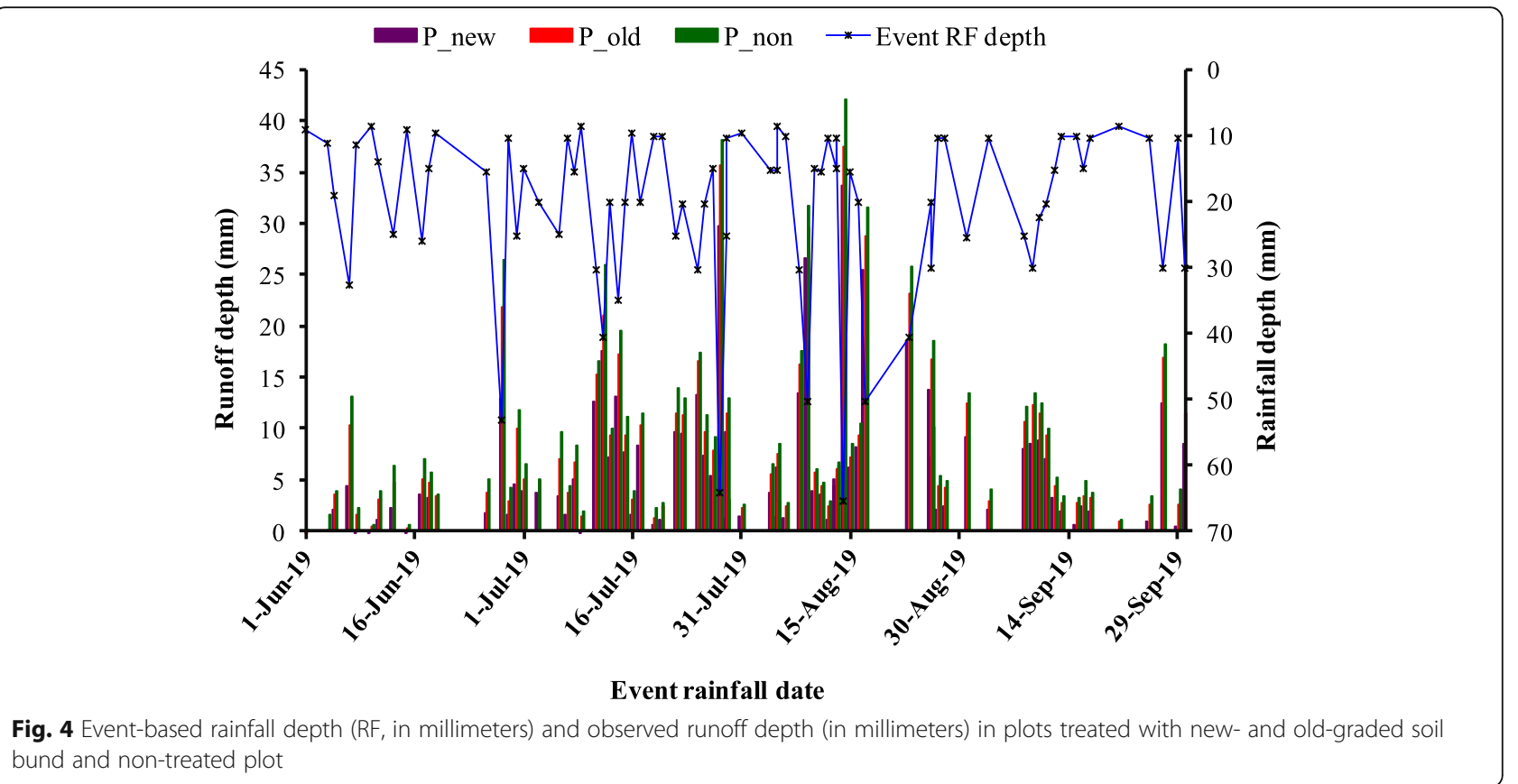


Table 2 Significance test results of runoff $(R)$, runoff coefficient $(R C)$, and soil loss $(S L)$ between plots with different treatments

\begin{tabular}{llll}
\hline Treatments & $\boldsymbol{R}(\mathbf{m m})$ & $\boldsymbol{R C}(\%)$ & $\boldsymbol{S L}(\mathbf{t ~ h a}$ \\
\hline New soil bund $\left(P_{\text {new }}\right)$ & 479.85 & 31.08 & 23.50 \\
Old soil bund $\left(P_{\text {old }}\right)$ & 644.61 & 41.75 & 45.56 \\
Non-treated $\left(P_{\text {non }}\right)$ & 737.51 & 47.77 & 58.15 \\
ANOVA F-ratio & $25.22^{\mathrm{a}}$ & $3.59^{\mathrm{b}}$ & $3.07^{\mathrm{b}}$ \\
\hline
\end{tabular}

"a " and "b" indicate the mean difference is significant at 0.001 and 0.05 , respectively

rainfall of 2 consecutive days (28 and 30 June 2019), was 18.9 and $32.5 \mathrm{~mm}$ but runoff reduction was 54.68 and $34.48 \%$, respectively. The infiltration capacity of heavy clay soils strongly decreases with increasing rainfall intensity and duration (Critchley et al. 1991a). This implies that since the rainfall is very high in the Gumara watershed (the long-term average rainfall is $\sim 2000 \mathrm{~mm}$ ), soil bunds need to be supported by other biological and physical measures that can facilitate water infiltration and hold a greater proportion of runoff.

The findings of this study are consistent with the results reported by Adimassu et al. (2014) in the central highlands of Ethiopia, Taye et al. (2013) in the semi-arid northern Ethiopia, Ebabu et al. (2019) in the Upper Blue Nile basin, and Haregeweyn et al. (2012) in northern Ethiopia. All these studies reported that plots treated with SWC generate significantly lower runoff volume as compared to the non-treated counterpart. Adimassu et al. (2014) indicated that soil bund-treated plots generate a significantly lower amount of runoff $(-28 \%)$ than conventional plots. A $27 \%$ reduction of runoff volume was observed in the Enabered watershed (Haregeweyn et al. 2012). A plot-based evaluation of the effect of SWC showed a rise of runoff volume by 2 times in the non-conserved than the conserved plot in China (Zhao et al. 2019).

This is because the soil surface around SWC structures is characterized by high water infiltration (Taye et al. 2013). Conservation structures can act as a sink system of runoff, which consequently reduces overland flow (Taye et al. 2013). Further, they act as a barrier to the moving water and decrease the energy of runoff by decreasing slope length and steepness. The use of SWC structures decreases slope steepness by $1 \%$ every three years (Nyssen et al. 2007). The steepness and length of the slope determine the velocity and volume of runoff (Prasannakumar et al. 2012), which considerably affects the rate of soil erosion (Gashaw et al. 2017).

On the other hand, $P_{\text {new }}$ reduced the annual runoff depth by $25.56 \%$ compared to that of the $P_{\text {old }}$. But the relative effect is slightly lower than with that of $P_{\text {non }}$. Nevertheless, the mean difference between $P_{\text {new }}$ and $P_{\text {old }}$ was not statistically significant $(P>0.05)$. Similarly, the annual runoff generated from $P_{\text {old }}$ was smaller than that of the $P_{\text {non }}$ by $12.6 \%$, but ANOVA could not detect the difference at $P<0.05$. This implies that the effect of old and un-maintained soil bund does not show a significant runoff reduction. This is mainly because after a certain years (mostly from 3-5 years) particularly on the cultivated land, the bund furrows nearly totally filled with sediments through runoff, plowing, or animal effect (free grazing is a common practice). Furrows at the beginning are constructed with a known depth and width purposefully to trap sediments and runoff until it overflows to a channel. But, when the furrows become filled, they do not hold any more sediment and runoff, although their effectiveness in decreasing the slope length and steepness is still important. This result implies that the effectiveness of SWC structures in reducing runoff diminishes as of time unless continued maintenance. Hence, frequent maintenance of bunds and sediment removal is needed (Wolancho 2015). But, conversely, maintenance of structures particularly making furrows empty for the next rainy season has been very limited in the watershed (Belayneh et al. 2019b).

\section{Effects on the runoff coefficient}

The runoff coefficient indicates the water infiltration and retaining capacity (including a portion of water lost through evaporation and transpiration) of specific land use or SWC treatment. The runoff coefficient can also imply how much rainfall becomes runoff (Adimassu and Haile 2011). Land use and its treatment generating the

Table 3 Multiple comparisons of mean differences of runoff $(R)$, runoff coefficient $(R C)$, and soil loss (SL) between the three treatments

\begin{tabular}{|c|c|c|c|c|}
\hline \multirow[t]{2}{*}{ Treatments $(l)$} & \multirow[t]{2}{*}{ Treatments $(J)$} & \multicolumn{3}{|c|}{ Mean difference $(I-J)$} \\
\hline & & $R(\mathrm{~mm})$ & $R C(\%)$ & $S L\left(\mathrm{t} \mathrm{ha}^{-1}\right)$ \\
\hline \multirow[t]{2}{*}{ New soil bund $\left(P_{\text {new }}\right)$} & Old soil bund ( $\left.P_{\text {old }}\right)$ & -2.17 & $-11.23^{a}$ & -0.29 \\
\hline & Non-treated $\left(P_{\text {non }}\right)$ & $-3.39^{b}$ & $-17.19^{a}$ & $-0.46^{b}$ \\
\hline \multirow[t]{2}{*}{ Old soil bund $\left(P_{\text {old }}\right)$} & New soil bund $\left(P_{\text {new }}\right)$ & 2.17 & $11.23^{\mathrm{a}}$ & 0.29 \\
\hline & Non-treated $\left(P_{\text {non }}\right)$ & -1.22 & $-5.96^{\mathrm{b}}$ & -0.16 \\
\hline \multirow[t]{2}{*}{ Non-treated $\left(P_{\text {non }}\right)$} & New soil bund $\left(P_{\text {new }}\right)$ & $3.39^{b}$ & $17.19^{\mathrm{a}}$ & $0.46^{\mathrm{b}}$ \\
\hline & Old soil bund $\left(P_{\text {old }}\right)$ & 1.22 & $5.96^{\mathrm{b}}$ & 0.16 \\
\hline
\end{tabular}

"a" and "b" indicate the mean difference is significant at 0.001 and 0.05 , respectively 
lowest runoff amount imply its high ability to hold and infiltrate water, and consequently decrease runoff and soil loss. It can increase an understanding that how much of the rainfall can be converted to on-site sinks and retained instead of to be a runoff for each SWC treatment.

The runoff coefficient results show greater disparity among treatments. The lowest runoff coefficient was recorded in the $P_{\text {new }}(31.08 \%$; Table 1$) . P_{\text {new }}$ reduced runoff coefficient by $34.9 \%$ and $25.6 \%$ against the $P_{\text {old }}$ and $P_{\text {non }}$, respectively. The variation in runoff coefficient between $P_{\text {new }}(31.08 \%), P_{\text {old }}(41.75 \%)$, and $P_{\text {non }}(47.77 \%)$ is significant (Table 2; $P<0.001$ ). Similarly, from the multiple comparison analysis results of the runoff coefficient, significant differences were observed between $P_{\text {new }}$ with $P_{\text {old }}$ and $P_{\text {non }}(P<0.001)$ and $P_{\text {old }}$ with $P_{\text {non }}$ (Table $3 ; P<0.05)$. This result is slightly higher than the finding of Adimassu et al. (2014), who reported a reduction of runoff coefficient by $19 \%$ compared against the nonconserved plots in central Ethiopia. On the other hand, our result is much lower than that of the finding of Nyssen et al. (2010), who reported increased infiltration rate and a reduction of runoff coefficient by $81 \%$ in the May Zegzeg catchment. A long-term plot data-based metaanalysis result in Europe and the Mediterranean showed a mean annual runoff coefficient ranging from 5 to $10 \%$ in bare soils, tree crops, and vineyards (Maetens et al. 2012b). This is a very low result compared to that of the Gumara watershed. The runoff coefficient from runoff plots having an area of less than $200 \mathrm{~m}^{2}$ is highly variable, ranging from 0 to $50 \%$ (Nyssen et al.
2010). The observed variation may be related to the prevailing characteristics of the plot in terms of soil type, type of land use, intensity, and amount of rainfall (Adimassu et al. 2014; Nyssen et al. 2010).

However, as it was observed on runoff, the effect of the soil bund on runoff coefficient decreased as it becomes older without regular maintenance. This was observed by an increase of runoff coefficient by $34.32 \%$ as compared to $P_{\text {new }}$ and showed reduction only by $12.5 \%$ from the $P_{\text {non }}$. On the other hand, the runoff coefficient continuously increases from the start to the end of the rainy season (Table 1). A similar trend was also observed regardless of the treatments (Gebreegziabher et al. 2009). The reason might be attributed to the increasing water table, stabilization of the soil, and crop covers. Nyssen et al. (2007) explained that the runoff coefficient becomes higher when vegetation cover decreases.

\section{Effects on soil loss}

Event-based sediment concentration $\left(\mathrm{g} \mathrm{L}^{-1}\right)$ and monthly and annual total soil loss $\left(\mathrm{tha}^{-1}\right)$ are presented in Fig. 5 and Table 4. Unlike that of runoff and runoff coefficient, sediment loss in all the treatments was decreasing continuously from the start to the end of the rainfall season. At the beginning of June (5 June 2019), 9.1, 13.8, and $14.5 \mathrm{~g} \mathrm{~L}^{-1}$ of sediment concentration was recorded for a $32.5-\mathrm{mm}$ rainfall depth from $P_{\text {new }}, P_{\text {old }}$, and $P_{\text {non }}$, respectively. But, at the ending of August (26 August 2019), the observed sediment concentration value for the same rainfall depth (30.1 mm) was 0.9, 2.9, and $3.4 \mathrm{~g} \mathrm{~L}^{-1}$ (Fig. 5), showed a drastic reduction. Similarly, regardless of the

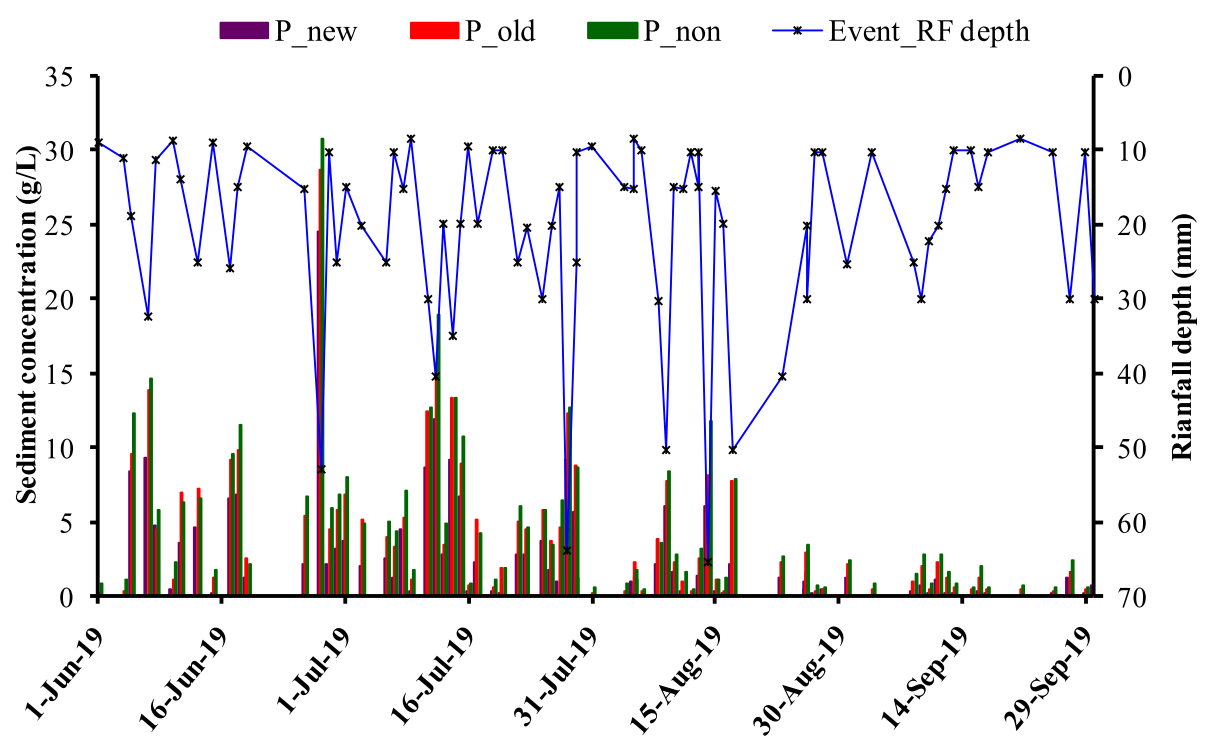

Rainfall event date

Fig. 5 Event-based rainfall depth ( $R F$, in millimeters) and sediment concentration (SC, in $\mathrm{g} \mathrm{L}^{-1}$ ) were observed in the new-and old-graded soil bund-treated and non-treated plots 
Table 4 Monthly and annual soil loss (SL) of treatments and the relative effect (RE) of graded soil bund treated as compared to the non-treated plots

\begin{tabular}{|c|c|c|c|c|c|}
\hline \multirow[t]{2}{*}{ Treatment } & \multicolumn{3}{|c|}{ Monthly } & \multicolumn{2}{|c|}{ Annual (four months) } \\
\hline & Month & $S L\left(\mathrm{tha}^{-1}\right)$ & $R E^{c}(\%)$ & $\overline{S L\left(\mathrm{tha}^{-1}\right)}$ & $R E^{c}(\%)$ \\
\hline \multirow[t]{4}{*}{ New soil bund $\left(P_{\text {new }}\right)$} & Jun & 5.75 & $-63.69^{a}\left(-52.6^{b}\right)$ & 23.50 & $-59.59^{a}\left(-48.3^{b}\right)$ \\
\hline & July & 11.53 & $-54.51^{\mathrm{a}}\left(-44.2^{\mathrm{b}}\right)$ & & \\
\hline & Aug. & 5.74 & $-61.27^{a}\left(-49.3^{b}\right)$ & & \\
\hline & Sep. & 0.48 & $-77.75^{a}\left(-67.1^{b}\right)$ & & \\
\hline \multirow[t]{4}{*}{ Old soil bund $\left(P_{\text {old }}\right)$} & Jun & 12.13 & -23.44 & 45.56 & -21.66 \\
\hline & July & 20.66 & -18.47 & & \\
\hline & Aug. & 11.31 & -23.65 & & \\
\hline & Sep. & 1.45 & -32.38 & & \\
\hline \multirow[t]{4}{*}{ Non-treated $\left(P_{\text {non }}\right)$} & Jun & 15.85 & - & 58.15 & - \\
\hline & July & 25.34 & - & & \\
\hline & Aug. & 14.81 & - & & \\
\hline & Sep. & 2.14 & - & & \\
\hline
\end{tabular}

SL is monthly and annual soil loss (in tha ${ }^{-1}$ ), $R E$ is the relative effect of treatments on runoff (in percent), and "al" and "b" are the relative effects of $P_{\text {new }}$ compared to $P_{\text {non }}$ and $P_{\text {old }}$, respectively

${ }^{C}$ The relative effect is calculated by considering the runoff from non-treated plot $100 \%$

high variation of monthly rainfall depth (293.6 and 483.5 $\mathrm{mm}$ in June and August, respectively), the rates of soil loss were $5.75,12.13$, and $15.85 \mathrm{tha}^{-1}$ in June and 5.74, 14.31, and $14.81 \mathrm{t} \mathrm{ha}^{-1}$ in August for $P_{\text {new }}, P_{\text {old }}$, and $P_{\text {non }}$, respectively (Table 4). This shows that the rate of sediment loss is nearly similar irrespective of the greater variation of rainfall depth of months.

During the start of the monsoon rainfall mainly in June up to July, most of the cultivated land has been bare and the soil disturbed through tillage (preparation of the land for sowing). These situations make the soil easily detachable, transportable, and more vulnerable for splash and rill erosion, which could probably cause high sediment concentration. However, in August and September, the growth of crop canopy, attachment of soil by crop roots, and stabilization of tillage-disturbed soils decrease the vulnerability of the soil for splash and rill erosion. Vegetation cover in cultivated plots increases from nearly zero during May and June (start of the rainy season) to exceeding $84 \%$ around September (end of the rainy season; Taye et al. 2013). The concentration of sediments within an event runoff decreases as crops growing in cultivated fields even in an increasing rainfall (Gebreegziabher et al. 2009). The growth of crops protects the soil surface from raindrop impact and slowdown runoff speed (Gebreegziabher et al. 2009; Taye et al. 2013). On the contrary, our result was not consistent with the finding of Gebreegziabher et al. (2009), who reported increased total soil loss due to the rise in runoff volume in the Gum Selasa area of Southern Tigray. In line with this, Bewket and Sterk (2003) described that plowing the soil created large rainwater storage space, minimized soil erosion, and increases infiltration capacity. But, on the other hand, Taye et al. (2013) argued that the effect of tillage on water storage and infiltration was found to be minimal due to the impact of the raindrop, crust formation, and sediment infilling.

The contribution of peak rainfall events to the total seasonal sediment loss in the season was high. For instance, a peak rainfall event $(53 \mathrm{~mm})$ occurring on 28 June 2019 on bare and disturbed soils contributed 16.14, 15.31 , and $15.33 \%$ of the total sediment loss from plots under $P_{\text {new }}, P_{\text {old }}$, and $P_{\text {non }}$, respectively. Similarly, seven rainfall events (with $\geq 30 \mathrm{~mm}$ ) covering $20 \%$ of the total seasonal rainfall represents $66.7 \%$ of the seasonal sediment loss from the $P_{\text {new }}$. Most of these events are occurred in June and July where the land was barren and disturbed for sowing crop seeds. As a result, a high rainfall in the exposed land (without land cover) can cause easily and high removal of sediment. Besides, high and torrential rainfall with high intensity led to high flow accumulation and consequently has high energy to detach and transport sediments. The amount, intensity, size of raindrop, duration, pattern, and associated runoff exerts influence on erosion (Farhan and Nawaiseh 2015). In association with a high intensity of rainfall, the raindrop size, and its kinetic energy increases and strongly dispatch soil particles and aggregates. This can make the soil to be easily transported by runoff and/or fine particulates can cause clogging of soil pores and limit infiltration (Critchley et al. 1991a). Several research results reported the dominancy of some peak rainfall events from the catchment total soil loss. The contribution of daily peak sediment load in different catchments of the Debre Mewi 
watershed ranged from 25 to $75 \%$ (Dagnew et al. 2017). Gonzalez-Hidalgo et al. (2010) reported that five of the peak rainfall events produce about $50 \%$ of the total soil loss in different catchments in USA. Three largest rainfall events contributed from 25 to $71 \%$ of the total sediment loss in the central-western Pyrenees, Asia (Romero et al. 2012).

The event, monthly, and seasonal soil losses were relatively lower in the $P_{\text {new }}$ followed by $P_{\text {old }}$, but it was exceptionally high in the $P_{\text {non }}$. In total, the highest amount of soil loss was observed in the $P_{\text {non }}\left(58.15 \mathrm{tha}^{-1}\right)$, twice as much as in the $P_{\text {new }}$, and even 1.6 times higher than that of $P_{\text {old }}$ (Table 4). The rate of soil loss in the $P_{\text {new }}$ was found to be $23.5 \mathrm{tha}^{-1}$ year $^{-1}$. Newly constructed soil bund reduced annual soil loss by 59.6 and $48.3 \%$ as compared to $P_{\text {non }}$ and $P_{\text {old }}$, respectively. However, the observed difference between $P_{\text {old }}$ and $P_{\text {non }}$ was comparatively smaller, i.e., only $21.7 \%$ lower in the $P_{\text {old }}$. The total amount of soil loss during the rainy months was significantly reduced due to newly constructed soil bund $\left(P_{\text {new }}\right)$ as compared to $P_{\text {non }}(P<0.05)$, but not with that of $P_{\text {old }}$ and between $P_{\text {old }}$ and $P_{\text {non }}(P>0.05$; Table 3$)$. As all plots were similar in all parameters other than bund treatment and age, the variations in sediment loss generated from experimental plots were attributed to the implementation of bund treatments and its age.

Several previously conducted studies reported a significant reduction of soil loss as a result of SWC implementation. Haregeweyn et al. (2012) and Taye et al. (2013) observed that conservation practices have reduced annual soil loss by $89 \%$ and $40 \%$ in northern Ethiopia. Adimassu et al. (2014) in the central highlands reported a soil loss rate of $24 \mathrm{tha}^{-1}$ and $50 \mathrm{tha}^{-1}$ from plots treated with soil bund and non-treated plots, respectively. On average, annually, sheet, rill, and tillage erosion contributed $57.26 \mathrm{tha}^{-1}$ and $18.64 \mathrm{tha}^{-1}$ in partially conserved and totally conserved cultivated plots in Zala Daget, northern Ethiopia (Nyssen et al. 2007). A comparatively lower amount of soil loss observed in the conserved plots is mainly attributed to a greater proportion of sediments trapped by the bund furrows. Similarly, Gebremichael et al. (2005) reported that a measured amount of $119 \mathrm{~kg} \mathrm{~m}^{-1}$ year $^{-1}$ soil was accumulated behind stone bunds in Tigray highlands.

On the other hand, our findings have been much greater than that of the findings of Taye et al. (2013), who reported $7.2,4.3$, and $1.1 \mathrm{tha}^{-1}$ in the non-treated, stone bund, and stone bund with trench-treated cultivated fields, respectively, in the Mayleba catchment. Similarly, rolling cultivated land treated with stone bunds generates $9.9 \mathrm{tha}^{-1}$ year $^{-1}$ of soil due to sheet and rill erosion in the Zala Daget, northern Ethiopia (Nyssen et al. 2007). The observed variation may be caused due to the existence of high ( $2000 \mathrm{~mm}$ long-term average) and erosive rainfall in the Gumara watershed as compared to its low depth in northern Ethiopia (724 mm long-term average in the Mayleba catchment). Sheet and rill erosion have relatively little importance in northern Ethiopia ( $\mathrm{Ti}$ gray), mainly due to the fact that much of the soils have already been removed, less rainfall, and active implementation of SWC implementation (Nyssen et al. 2007).

Research results in different parts of the world also acknowledged the effect of SWC. Plot-based evaluation of the effect of SWC conducted by Zhao et al. (2019) in China resulted in a soil loss rate of 3.5 times larger in non-conserved $\left(28.63 \mathrm{tha}^{-1} \mathrm{year}^{-1}\right)$ than the conserved plots $\left(8.63 \mathrm{tha}^{-1}\right.$ year $\left.^{-1}\right)$. Anache et al. (2017) reported that annual soil loss in the agricultural land ranges from 7.7 to $14.4 \mathrm{t} \mathrm{ha}^{-1}$ year $^{-1}$ in Brazil. A plot data-based study result in Europe and the Mediterranean showed a mean annual soil loss rate of $10-20 \mathrm{tha}^{-1}$ in bare soils, tree crops, and vineyards (Maetens et al. 2012b). A study by Panagos et al. (2015) in the European Union reported a mean soil erosion rate of 2.46 in the erosion prone areas including agricultural land. As compared to these, soil erosion in the Gumara watershed is relatively high. High rainfall, intensive cultivation, and heavy clay nature of the soil may cause the variation.

Bunds accumulate a greater proportion of sediments at its young age, but the rate of accumulation decreases with increasing age due to lack of regular maintenance (Gebremichael et al. 2005). The effect of SWC structures more likely diminishes with time due to damage of structures and sediment infilling (Taye et al. 2015; Gebreegziabher et al. 2009; Gebremichael et al. 2005). Similarly, in the current study, the amount of soil loss in the $P_{\text {old }}$ was much greater than that of the $P_{\text {new }}$. This is due to the infilling of depression behind soil bunds with sediments by runoff erosion, tillage operations, and animal and human effects. This implies the significance of soil bund maintenance (renewing) on both runoff and soil loss reduction. However, structures in its new or old form affect the slope length and steepness, which can reduce soil erosion. Runoff travels at a high speed in steeper slopes, increases its shear stress on the surface, and transports a high amount of sediment (Wischmeier and Smith 1978).

In general, the result of this study showed that the implementation of SWC measures had reduced total soil loss significantly, particularly the newly constructed graded soil bund. However, the rate of soil loss observed in all the treatments is much greater than both the tolerable limit (1-6 tha ${ }^{-1}$ year $^{-1}$ ) (Hurni 1983b) and the rate of soil formation $\left(10-14 \mathrm{tha}^{-1}\right.$ year $\left.^{-1}\right)$ estimated for the study area (for Gojjam, Hurni 1983a).

\section{The relationship between rainfall-runoff-soil loss under different treatments} Monthly and annual rainfall-runoff relationship

The monthly and annual rainfall and runoff relationship under different treatments are shown in Fig. 6. In all the 

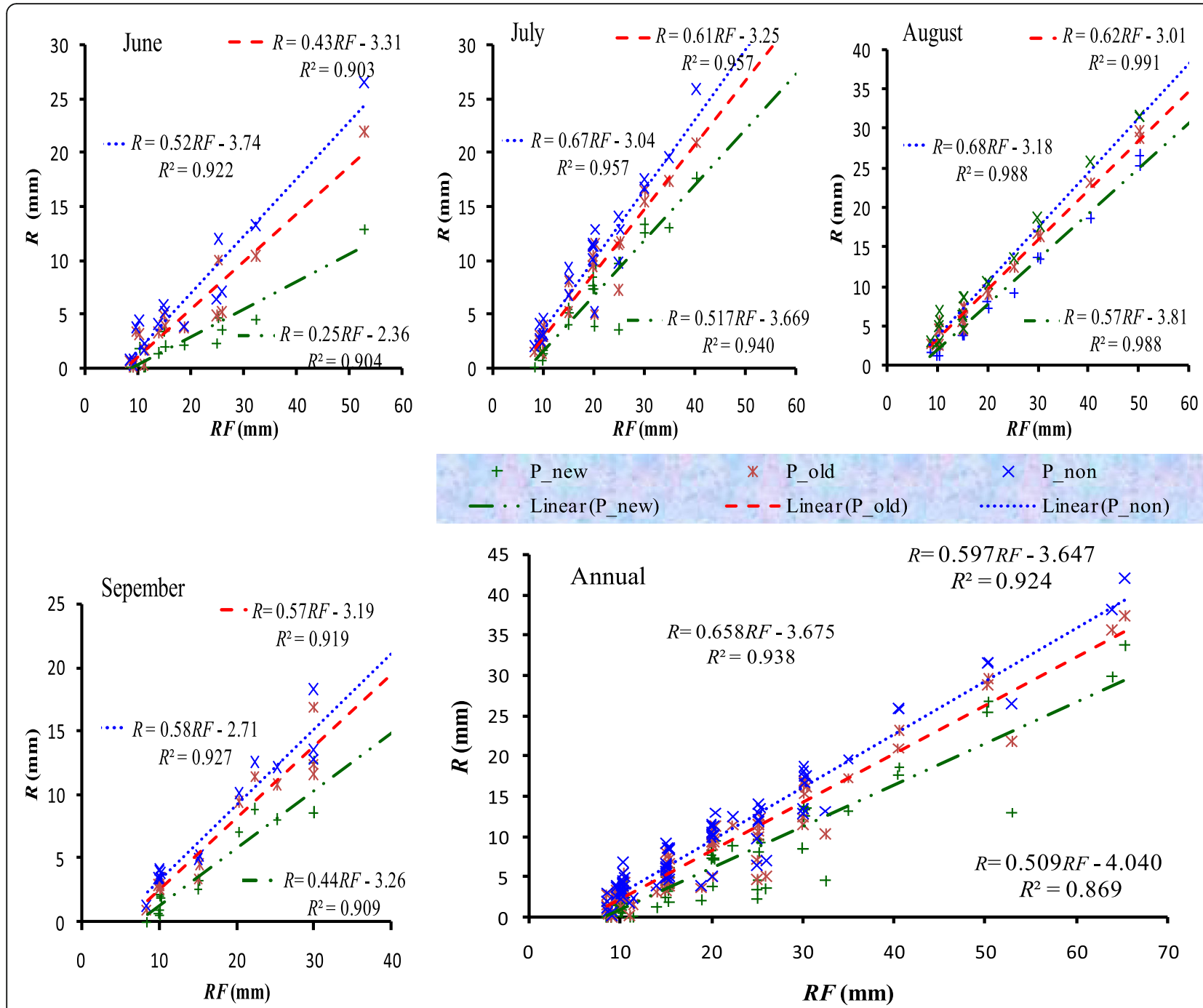

Fig. 6 Monthly and annual rainfall-runoff relationship under different conservation treatments

rainy months the correlation was strong but it becomes highest in August $\left(R^{2}=0.988,0.988\right.$, and 0.991 for $P_{\text {new }}$, $P_{\text {old }}$, and $P_{\text {non }}$, respectively). In total, the annual $R^{2}$ value was higher in the $P_{\text {non }}\left(R^{2}=0.94\right)$ and lower in the $P_{\text {new }}$ $\left(R^{2}=0.87\right)$. The correlation of rainfall and runoff in $P_{\text {new }}$ was not as strong as that of the $P_{\text {old }}$ and $P_{\text {non }}$, because of the existence of bund furrows and its variation in the water holding capacity in different months and intensity of rainfall events. The high coefficient of determination result implies that monthly and annual rainfall and runoff have a positive strong relationship in all the treatments. Although significant variation was observed between treatments, the relationship of rainfall and runoff for all studied plots were strong (Fig. 6). This result is in agreement with the findings of Adimassu et al. (2014), who reported a strong and significant relationship between rainfall and runoff in the central highlands of Ethiopia.
The $R^{2}$ value for all plots showed that the correlation could not be altered by the implementation of SWC measures. This is an important indication that runoff is highly influenced by the prevailing rainfall regardless of the treatments.

\section{Monthly and annual rainfall-soil loss relationship}

Figure 7 shows the monthly and annual relationship between rainfall and soil loss for $P_{\text {new }}, P_{\text {old }}$, and $P_{\text {non }}$. The linear relationship indicates a strong correlation between rainfall and soil loss in all treatments. The $R^{2}$ value showed that the highest relationship for $P_{\text {new }}\left(R^{2}=0.85\right)$ was observed in July but the lowest in all months as compared to $P_{\text {old }}$ and $P_{\text {non }}$. The relationship continuously increases starting from June to August and starts to decline in September for all treatments. This might be related to the depth of rainfall and the crop cover of the land. The correlation was stronger in $P_{\text {old }}$ for all months. 

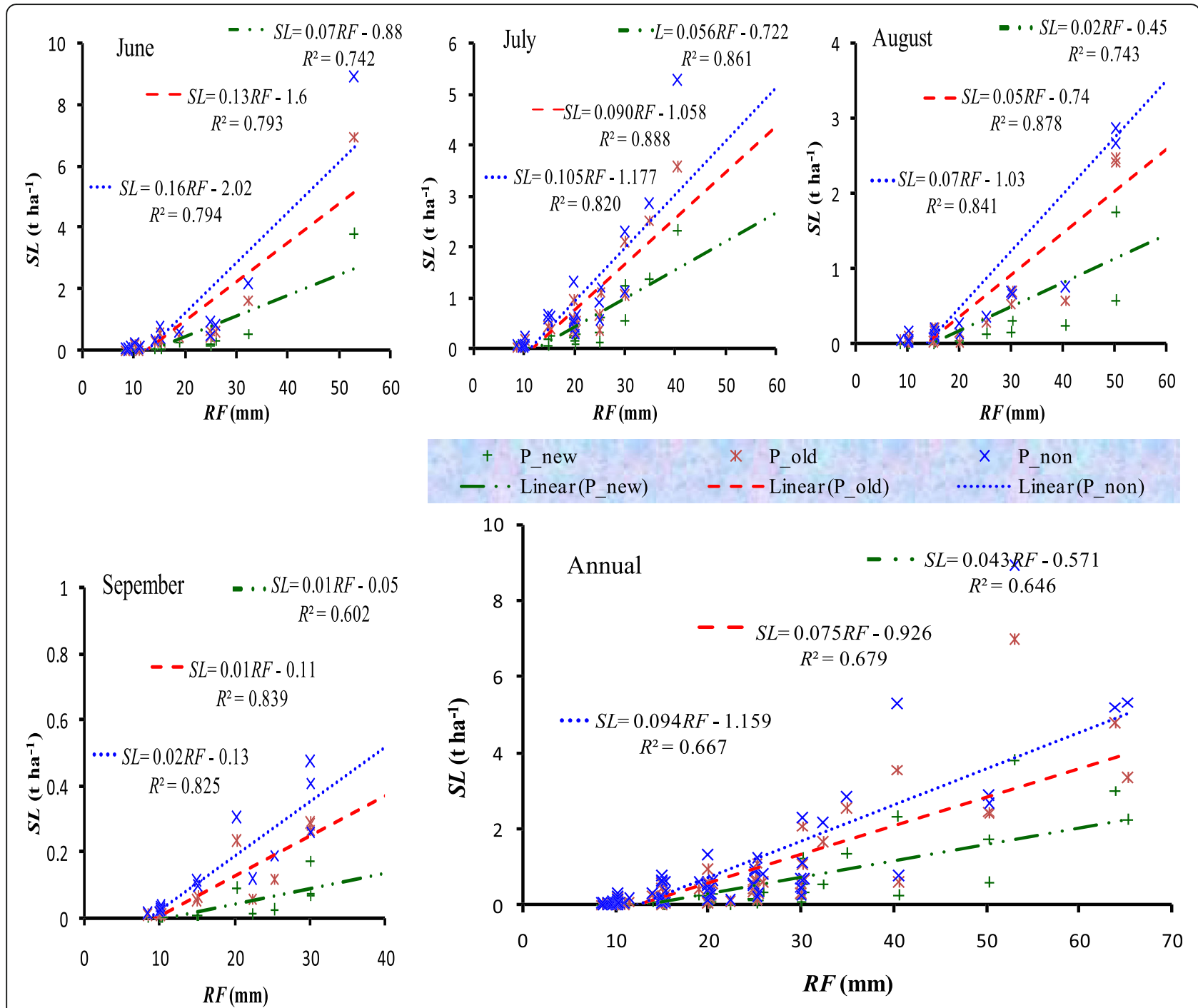

Fig. 7 Rainfall-sediment loss relationship within plots treated with new soil bund, old soil bund, and non-treated

On the other hand, the observed relationship between annual rainfall and soil loss was found much lower than that of monthly basis for all treatments (Fig. 7). But, as compared to rainfall with runoff, the correlation is less strong with soil loss. A strong and significant correlation between rainfall and soil loss was observed in the central highlands of Ethiopia (Adimassu et al. 2014).

\section{Monthly and annual runoff-soil loss relationship}

A positive and strong correlation was observed between annual runoff and soil loss for all treatments (Fig. 8). The relationship of runoff and soil loss for $P_{\text {new }}$ was stronger in June $\left(R^{2}=0.86\right)$ and July $\left(R^{2}=0.85\right)$ but decreased in August $\left(R^{2}\right.$ $=0.75)$ and September $\left(R^{2}=0.68\right)$. Although the reduction in $R^{2}$ was observed in $P_{\text {old }}$ and $P_{\text {non }}$, the highest was recorded in the $P_{\text {new }}$. This is because the occurrence of a high amount of runoff on disturbed bare agricultural soils at the start of the rainy season can cause high runoff-sediment concentration and vice versa. But, at the ending (August and September), sediment concentration becomes very low due to crop covers and soil sealing, and most of it may be left behind bunds even during high runoff. In general, as compared to rainfall with runoff and soil loss, a less strong correlation was observed between runoff and soil loss. This implies that other factors such as land use/cover, the stability of the soil, and treatments are also important factors to sediment loss together with that of runoff depth. The result is in agreement with the findings of Adimassu et al. (2014) and Adimassu and Haile (2011), who reported a significant relationship between runoff and soil loss.

\section{Limitations of the study}

This research had two main limitations. The first limitation is that the study used two replicates for each 

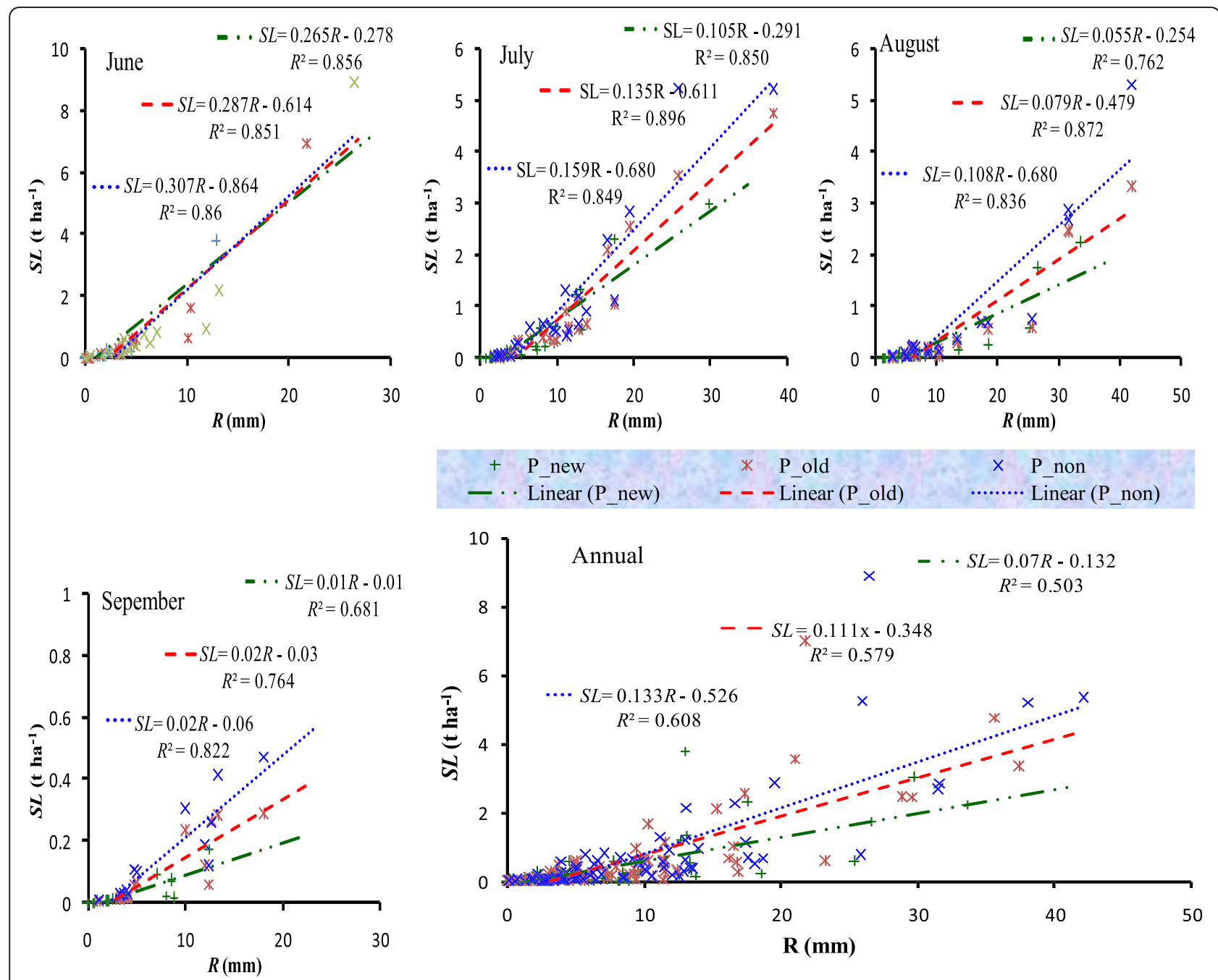

Fig. 8 Runoff-soil loss relationship within plots treated with new soil bund, old soil bund, and non-treated

treatment. Because of its nature of high financial and labor requirements, the treatments were replicated two times. Secondly, the data was collected for 1 year (one rainy season comprising of greater than $70 \%$ the annual rainfall). This is mainly because of the financial limitations of the study. Therefore, the results of the study can be interpreted in view of these limitations. Further studies with large number of replicates of treatments and covering more rainfall seasons are recommended to consider the effect of seasonal variations and better average results from replicates.

\section{Conclusion and implications}

This study investigated the effect of the most commonly implemented graded soil bund (new and 11 years) in reducing runoff and soil loss. Rainfall, runoff, and sediment concentration were observed using erosion plots in the 2019 summer rainfall months. The results of the study showed that graded soil bund in its new form significantly reduced runoff, runoff coefficient, and soil loss $(P<0.05)$ but the effect of its old equivalent was only on runoff coefficient $(P<0.05) . P_{\text {new }}$ reduced runoff by $34.94 \%$ and $25.56 \%$ as compared to that of the old and non-treated counterparts, respectively. However, the effect of the $P_{\text {old }}(12.6 \%)$ was much lower than that of the $P_{\text {new }}$. Runoff and runoff coefficient continuously increased from the start to the end of the rainy season. It is mainly due to increased saturation of the soil and crop cover at the end of the rainy season and vice versa. Similarly, the highest amount of soil loss was observed in the $P_{\text {non }}$, twice as much as in the $P_{\text {new }}$ and even 1.6 times higher than that of $P_{\text {old }}$. The rate of soil loss in the $P_{\text {new }}, P_{\text {old }}$, and $P_{\text {non }}$ was found to be $23.5,45.56$, and $58.15 \mathrm{t} \mathrm{ha}^{-1}$ year $^{-1}$, respectively. This shows a net soil loss reduction by 59.6 and $48.3 \%$ compared to the old and non-treated plots. Sediment concentration and total soil loss were very high at the beginning of the rainy season (June and July) than at the ending, because, at the 
start, most of the cultivated land was bare and disturbed through tillage, which makes the soil easily detachable, transportable, and vulnerable to splash and rill erosion. Later on, the concentration becomes reduced due to the stabilization of the soil and improved crop cover.

$P_{\text {new }}$ with furrow depressions was found most effective in runoff and sediment loss reduction as compared to the $P_{\text {old }}$ and $P_{\text {non }}$. The reduction in runoff and sediment loss in the $P_{\text {new }}$ is attributed to the furrows constructed as depressions to trap runoff and soil loss. However, the effect of bunds was not limited due to furrows with sufficient depressions and also in old soil bunds in which furrows are nearly totally filled with sediments. In general, conservation structures showed important implications to reduce runoff and sediment loss in the subhumid Gumara watershed. The runoff and soils protected from erosion can improve ground water recharge, soil fertility, better plant growth, and finally increase agricultural productivity. A positive and significant correlation was observed between rainfall, runoff, and soil loss regardless of the treatments.

Although soil bund reduced a significant amount of runoff and sediment loss, the net soil loss even in treated plots was very high. Thus, graded soil bunds need to be supported by different SWC measures that can facilitate infiltration and trap sediments such as grass strips, physical structures, and agro-forestry practices with leguminous trees. Therefore, it is recommended that the government together with the local residents and NGOs (where possible) need to develop a culture of regular maintenance and implement supportive SWC measures at the micro-watershed level for sustained reduction of soil erosion and make it below the tolerance limit.

\section{Abbreviations}

ANOVA: Analysis of variance; CSA: Central Statistical Authority; NGOs: Nongovernmental organizations; SPSS: Statistical Packages for Social Scientists; SWC: Soil and water conservation; UBNB: Upper Blue Nile basin

\section{Acknowledgements}

The study was financed by Arba Minch University. Data collection enumerators are gratefully acknowledged for their greater assistance in data collection. The authors would like to acknowledge Mr. Amare of the agricultural expert for Shangi kebele and farmers who allow their cultivated land for this experiment. Finally, we acknowledge Debre Markos soil research and fertility improvement laboratory and Debre Markos University for allowing their laboratories for sediment filtration and oven-drying. We thank the editor and two anonymous reviewers' for their substantial comments and suggestions.

\section{Authors' contributions}

$\mathrm{MB}$ has made a significant contribution to the conception and designing of the study, data collection, sediment concentration analysis, data analysis, interpretation of the results, and prepared the manuscript. TY and DT have contributed to designing the study, supervising the study, editing, commenting, and suggesting ideas in the manuscript preparation process. Finally, all authors read and approved the final manuscript for publication.

\section{Authors' information}

Mengie Belayneh is an Assistant Professor and Lecturer in the Department of Geography and Environmental Studies, Mettu University, Mettu, Ethiopia.
Mengie Belayneh gained his Bachelor and Master's Degree in the Department of Geography and Environmental Studies at Wollo University and the Mekelle University of Ethiopia, respectively. Currently, he is a Ph.D. student in Environment and Natural Resources Management in the Department of Geography and Environmental Studies, Arba Minch University, Ethiopia.

\section{Funding}

The first author acknowledges Arba Minch University for financial support of this study.

Availability of data and materials

The datasets used and/or analyzed during the current study are available from the corresponding author on reasonable request.

\section{Ethics approval and consent to participate}

Not applicable.

\section{Consent for publication}

All authors agreed and approved the manuscript for publication in Ecological Processes.

\section{Competing interests}

The authors declare that they have no competing interests.

\section{Author details}

${ }^{1}$ Department of Geography and Environmental Studies, Arba Minch University, P.O. Box 21, Arba Minch, Ethiopia. ${ }^{2}$ Department of Geography and Environmental Studies, Mettu University, P.O. Box 318, Mettu, Ethiopia. ${ }^{3}$ Department of Plant Science, College of Agricultural Sciences, Arba Minch University, P.O. Box 21, Arba Minch, Ethiopia.

Received: 22 July 2020 Accepted: 23 October 2020

Published online: 03 December 2020

\section{References}

Abbate E, Bruni P, Sagri M (2015) Geology of Ethiopia: A review and geomorphological perspectives. In: Billi P (ed) Landscapes and Landforms of Ethiopia. Springer, Dordrecht, pp 33-64.

Adgo E, Teshome A, Mati B (2013) Impacts of long-term soil and water conservation on agricultural productivity: the case of Anjenie watershed, Ethiopia. Agric Water Manag 117:55-61

Adimassu Z, Haile N (2011) Runoff, soil loss and their relationships under different land uses in the central highlands of Ethiopia. Ethiopian J Appl Sci Technol 2(1):39-49

Adimassu Z, Mekonnen K, Yirga C, Kessler A (2014) Effect of soil bunds on runoff, soil and nutrient losses, and crop yield in the central highlands of Ethiopia. Land Degrad Dev 25(6):554-564

Anache JA, Wendland EC, Oliveira PT, Flanagan DC, Nearing MA (2017) Runoff and soil erosion plot-scale studies under natural rainfall: a meta-analysis of the Brazilian experience. Catena 152:29-39

Bashari M, Moradi HR, Kheirkhah MM, Jafari-Khaledi M (2013) Temporal variations of runoff and sediment in different soil clay contents using simulated conditions. Soil Water Res 8(3):124-132

Belayneh M, Yirgu T, Tsegaye D (2019a) Potential soil erosion estimation and area prioritization for better conservation planning in Gumara watershed using RUSLE and GIS techniques. Environ Syst Res 8(1):20

Belayneh M, Yirgu T, Tsegaye D (2019b) Effects of soil and water conservation practices on soil physicochemical properties in Gumara watershed, Upper Blue Nile basin, Ethiopia. Ecol Process 8:36

Bewket W, Sterk G (2003) Assessment of soil erosion in cultivated fields using a survey methodology for rills in the Chemoga watershed, Ethiopia. Agric Ecosyst Environ 97:81-93

Bewket W, Teferi E (2009) Assessment of soil erosion hazard and prioritization for treatment at the watershed level: case study in the Chemoga watershed, Blue Nile basin, Ethiopia. Land Degrad Dev 20(6):609-622

Central Statistical Agency of Ethiopia (CSA) (2007) Statistical abstract of Ethiopia. Addis Ababa

Critchley W, Siegert K, Chapman C (1991a) Water harvesting: a manual for the design and construction of water harvesting schemes for plant production, 
Food and Agriculture Organization of the United Nations, RomeAGL. MISC/ $17 / 91$.

Dagnew A, Mekonnen H, Tilahun S, Haregeweyn N, Adgo E (2017) Investigating the impacts of soil and water conservation measures on hydrology and soil loss in humid Ethiopian highlands of Upper Blue Nile basin. In EuroMediterranean Conference for Environmental Integration. Springer, Cham, pp 1089-1090

Dagnew DC, Guzman CD, Zegeye AD, Tibebu TY, Getaneh M, Abate S, Zemale FA, Ayana EK, Tilahun SA, Steenhuis TS (2015) Impact of conservation practices on runoff and soil loss in the sub-humid Ethiopian highlands: the Debre Mawi watershed. J Hydrol Hydromech 63(3):210-219

Ebabu K, Tsunekawa A, Haregeweyn N, Adgo E, Meshesha DT, Aklog D, Masunaga T, Tsubo M, Sultan D, Fenta AA, Yibeltal M (2019) Effects of land use and sustainable land management practices on runoff and soil loss in the Upper Blue Nile basin Ethiopia. Sci Total Environ 648:1462-1475

Elliott AC, Woodward WA (2007) Statistical analysis quick reference guidebook: with SPSS examples. Sage publications, California

Environment for Development (2010) Green accounting puts price on Ethiopian soil erosion and deforestation.

Farhan Y, Nawaiseh S (2015) Spatial assessment of soil erosion risk using RUSLE and GIS techniques. Environ Earth Sci 74(6):4649-4669

Gashaw T, Tulu T, Argaw M (2017) Erosion risk assessment for prioritization of conservation measures in Geleda watershed, Blue Nile basin, Ethiopia. Environ Syst Res 6:1

Gebreegziabher T, Nyssen J, Govaerts B, Getnet F, Behailu M, Haile M, Deckers J (2009) Contour furrows for in situ soil and water conservation, Tigray, Northern Ethiopia. Soil Tillage Res 103(2):257-264

Gebremichael D, Nyssen J, Poesen J, Deckers J, Haile M, Govers G, Moeyersons J (2005) Effectiveness of stone bunds in controlling soil erosion on cropland in the Tigray Highlands, northern Ethiopia. Soil Use Manage 21(3):287-297

Gonzalez-Hidalgo JC, Batalla RJ, Cerdà A, De Luis M (2010) Contribution of the largest events to suspended sediment transport across the USA. Land Degrad Dev 21(2):83-91

Haregeweyn N, Berhe A, Tsunekawa A, Tsubo M, Meshesha DT (2012) Integrated watershed management as an effective approach to curb land degradation: a case study of the Enabered watershed in northern Ethiopia. Environ Manag 50(6):1219-1233

Haregeweyn N, Tsunekawa A, Nyssen J, Poesen J, Tsubo M, Meshesha DT, Schutt B, Adgo E, Tegegne F (2015) Soil erosion and conservation in Ethiopia: a review. Prog Phys Geogr 39(6):750-774

Haregeweyn N, Tsunekawa A, Poesen J, Tsubo M, Meshesha DT, Fenta AA, Nyssen J, Adgo E (2017) Comprehensive assessment of soil erosion risk for better land use planning in river basins: case study of Upper Blue Nile River Sci Total Environ 574:95-108

Haregeweyn N, Tsunekawa A, Tsubo M, Meshesha D, Adgo E, Poesen J, Schütt B (2016) Analyzing the hydrologic effects of region-wide land and water development interventions: a case study of the Upper Blue Nile basin. Regional Environ Change 16(4):951-966

Hudson N (1993) Field measurement of soil erosion and runoff (Vol. 68). Food \& Agriculture Organization of the United Nations, Rome

Hurni H (1983a) Soil formation rates in Ethiopia (with scale 1:1,000,000). Ethiopian highlands Reclamation Study, UTF/ETH/O37/ETH. Roma: FAO, Working Paper 2

Hurni H (1983b) Soil erosion and soil formation in agricultural ecosystems: Ethiopia and Northern Thailand. Mt Res Dev 3(2):131-142

Hurni H, Berhe W A, Chadhokar P, Daniel D, Gete Z, Grunder M, Kassaye G (2016) Soil and water conservation in Ethiopia: guidelines for development agents. Centre for Development and Environment, $2^{\text {nd }}$ ed., University of Bern, with Bern Open Publishing (BOP), Bern, 134

Hurni H, Debele B, Zeleke G (2015a) Saving Ethiopia's soils. In: Ehrensperger A Ott C, Wiesmann U (eds): Eastern and Southern Africa Partnership Programme: highlights from 15 years of Joint Action for Sustainable Development. Bern, Switzerland: Centre for Development and Environment, University of Bern with Bern Open Publishing, pp 27-30

Hurni K, Zeleke G, Kassie M, Tegegne B, Kassawmar T, Teferi E, Moges A, Tadesse D, Ahmed M, Degu Y, Kebebew Z, Hodel E, Amdihun A, Mekuriaw A, Debele B, Deichert G, Hurni H. (2015b) Soil degradation and sustainable land management in the rainfed agricultural areas of Ethiopia: an assessment of the economic implications. Report for the economics of land degradation initiative

Kothyari BP, Verma PK, Joshi BK, Kothyari UC (2004) Rainfall-runoff-soil and nutrient loss relationships for plot size areas of Bhetagad watershed in Central Himalaya, India. J Hydrol 293(1-4):137-150
Lemma H, Frankl A, van Griensven A, Poesen J, Adgo E, Nyssen J (2019) Identifying erosion hotspots in Lake Tana Basin from a multisite soil and water assessment tool validation: opportunity for land managers. Land Degrad Dev 30(12):1449-1467

Liu H (2015) Comparing Welch's ANOVA, a Kruskal-Wallis test and traditional ANOVA in case of heterogeneity of variance. Virginia Commonwealth University, Richmond, Virginia. Retrieved from https://scholarscompass.vcu. edu/etd/3985

Maetens W, Poesen J, Vanmaercke M (2012a) How effective are soil conservation techniques in reducing plot runoff and soil loss in Europe and the Mediterranean? Earth-Sci Rev 115(1-2):21-36

Maetens W, Vanmaercke M, Poesen J, Jankauskas B, Jankauskiene G, lonita I (2012b) Effects of land use on annual runoff and soil loss in Europe and the Mediterranean: a meta-analysis of plot data. Prog Phys Geogr 36(5):599-653

Mekuria W, Veldkamp E, Haile M, Nyssen J, Muys B, Gebrehiwot K (2007) Effectiveness of exclosures to restore degraded soils as a result of overgrazing in Tigray, Ethiopia. J Arid Environ 69(2):270-284

Mekuriaw A, Heinimann A, Zeleke G, Hurni H (2018) Factors influencing the adoption of physical soil and water conservation practices in the Ethiopian highlands. Int Soil Water Conserv Res 6(1):23-30

Ministry of Water Resources of Ethiopia (MoWR) (1998) Abbay river basin integrated development master plan, main report. Ministry of Water Resources, Addis Ababa

Morgan RPC (2005) Soil erosion and conservation, 3rd edn. Blackwell Publishing, Oxford Nyssen J, Clymans W, Descheemaeker K, Poesen J, Vandecasteele I, Vanmaercke M, Zenebe A, Van Camp M, Haile M, Haregeweyn N, Moeyersons J, Martens K, Gebreyohannes T, Deckers J, Walraevens K (2010) Impact of soil and water conservation measures on catchment hydrological response-a case in north Ethiopia. Hydrol Process 24(13):1880-1895

Nyssen J, Descheemaeker K, Haregeweyn N, Mitiku H, Deckers J, Poesen J (Eds.) (2007) Lessons learnt from 10 years research on soil erosion and soil and water conservation in Tigray. Tigray Livelihood Papers No. 7. Mekelle: ZalaDaget Project, Mekelle University, K.U. Leuven, Relief Society of Tigray, Africa Museum and Tigray Bureau of Agriculture and Rural Development

Nyssen J, Poesen J, Moeyersons J, Deckers J, Haile M, Lang A (2004) Human impact on the environment in the Ethiopian and Eritrean highlands - a state of the art. Earth-Sci Rev 64(3-4):273-320

Panagos P, Borrelli P, Poesen J, Ballabio C, Lugato E, Meusburger K, Montanarella $L$, Alewell C (2015) The new assessment of soil loss by water erosion in Europe. Environ Sci Policy 54:438-447

Prasannakumar V, Vijth H, Abinod S, Geetha N (2012) Estimation of soil erosion risk within a small mountainous sub-watershed in Kerala, India, using Revised Universal Soil Loss Equation (RUSLE) and geo-information technology. Geosci Front 3(2):209-215

Romero MEN, Martínez TL, González-Hidalgo JC, de Luis AM, Ruiz JMG (2012) The effect of intense rainstorm events on the suspended sediment response under various land uses: the Aísa Valley Experimental station. Cuad Investig Geogr 38:27-47

Satriawan H, Harahap EM, Karim A (2015) Effectiveness of soil conservation to erosion control on several land use types. Agriculture (Polnohospodárstvo) 61(2):61-68

Stevens JP (2007) Intermediate statistics: a modern approach, 3rd edn. Lawrence Erlbaum Associates, New York

Subhatu A, Lemann T, Hurni K, Portner B, Kassawmar T, Zeleke G, Hurni H (2017) Deposition of eroded soil on terraced croplands in Minchet catchment, Ethiopian highlands. Int Soil Water Conserv Res 5(3):212-220

Sultan D, Tsunekawa A, Haregeweyn N, Adgo E, Tsubo M, Meshesha DT, Masunaga S, Aklog D, Ebabu K (2017) Analyzing the runoff response to soil and water conservation measures in a tropical humid Ethiopian highland. Phys Geogr 38(5):423-447

Taddese G (2001) Land degradation: a challenge to Ethiopia. Environ Manag 27(6):815-824

Tamene L, Vlek PL (2008) Soil erosion studies in northern Ethiopia. In Land use and soil resources. Springer, Dordrecht, pp 73-100

Taye G, Poesen J, Vanmaercke M, Van Wesemael B, Martens L, Teka D, Nyssen J, Deckers J, Vanacker V, Haregeweyn N, Hallet V (2015) Evolution of the effectiveness of stone bunds and trenches in reducing runoff and soil loss in the semi-arid Ethiopian highlands. Zeitschrift für Geomorphologie 59(4):477-493

Taye G, Poesen J, Wesemael BV, Vanmaercke M, Teka D, Deckers J, Goosse T, Maetens W, Nyssen J, Hallet V, Haregeweyn N (2013) Effects of land use, slope gradient, and soil and water conservation structures on runoff and soil loss in semi-arid Northern Ethiopia. Phys Geogr 34(3):236-259 
Temesgen M, Uhlenbrook S, Simane B, Van Der Zaag P, Mohamed Y, Wenninger J, Savenije HHG (2012) Impacts of conservation tillage on the hydrological and agronomic performance of fanya juus in the upper Blue Nile (Abbay) river basin. Hydrol Earth Syst Sci 16:4725-4735

Urdan TC (2010) Statistics in plain English, 3rd edn. Taylor Francis, New York Wischmeier WH, Smith DD (1978) Predicting rainfall erosion losses: a guide to conservation planning (No. 537). Department of Agriculture, Science and Education Administration

Wolancho KW (2015) Evaluating watershed management activities of campaign work in Southern nations, nationalities and peoples' regional state of Ethiopia. Environ Syst Res 4(1):6

Yaekob T, Tamene L, Gebrehiwot SG, Demissie SS, Adimassu Z, Woldearegay K, Mekonnen K, Amede T, Abera W, Recha JW, Solomon D, Thorne P (2020) Assessing the impacts of different land uses and soil and water conservation interventions on runoff and sediment yield at different scales in the central highlands of Ethiopia. Renew Agr Food Syst. https://doi.org/10.1017/ S1742170520000010

Yibeltal M, Tsunekawa A, Haregeweyn N, Adgo E, Meshesha DT, Masunaga T, Tsubo M, Billi P, Ebabu K, Fenta AA, Berihun ML (2019) Morphological characteristics and topographic thresholds of gullies in different agroecological environments. Geomorphology 341:15-27

Zegeye AD, Langendoen EJ, Stoof CR, Tilahun SA, Dagnew DC, Zimale FA, Guzman CD, Yitaferu B, Steenhuis TS (2016) Morphological dynamics of gully systems in the sub-humid Ethiopian highlands: the Debre Mawi watershed. Soil 2(3):443-458

Zeleke G, Hurni H (2001) Implications of land use and land cover dynamics for mountain resource degradation in the Northwestern Ethiopian highlands. Mt Res Dev 21(2):184-191

Zhao J, Yang Z, Govers G (2019) Soil and water conservation measures reduce soil and water losses in China but not down to background levels: Evidence from erosion plot data. Geoderma 337:729-741

\section{Publisher's Note}

Springer Nature remains neutral with regard to jurisdictional claims in published maps and institutional affiliations.

\section{Submit your manuscript to a SpringerOpen ${ }^{\circ}$ journal and benefit from:}

- Convenient online submission

- Rigorous peer review

- Open access: articles freely available online

- High visibility within the field

- Retaining the copyright to your article

Submit your next manuscript at $\boldsymbol{\nabla}$ springeropen.com 